\title{
Strategies to Mitigate Chemotherapy and Radiation Toxicities That Affect Eating
}

\author{
Peter M. Anderson $1,2, * \mathbb{1}$, Stefanie M. Thomas ${ }^{1,2}$, Shauna Sartoski ${ }^{1,3}$, Jacob G. Scott ${ }^{2,4}$, Kaitlin Sobilo ${ }^{1,3}$, \\ Sara Bewley ${ }^{1,5}$, Laura K. Salvador ${ }^{6}$ and Maritza Salazar-Abshire ${ }^{6,7}$ \\ 1 Pediatric Hematology/Oncology and Bone Marrow Transplant, Cleveland Clinic Children's, \\ Cleveland, OH 44195, USA; thomass29@ccf.org (S.M.T.); sartoss@ccf.org (S.S.); sobilok@ccf.org (K.S.); \\ bewleys@ccf.org (S.B.) \\ 2 Taussig Cancer Institute, Cleveland Clinic, Cleveland, OH 44195, USA; scottj10@ccf.org \\ 3 Department of Nursing, Cleveland Clinic, Cleveland, OH 44195, USA \\ 4 Department of Radiation Oncology, Lerner Research Institute, Cleveland Clinic, Cleveland, OH 44195, USA \\ 5 Peds Nutritional Services, Cleveland Clinic, Cleveland, OH 44195, USA \\ 6 Department of Pediatrics, MD Anderson Cancer Center, Houston, TX 77030, USA; \\ lekaye@mdanderson.org (L.K.S.); msalaza@mdanderson.org (M.S.-A.) \\ 7 Department of Nursing Education, MD Anderson Cancer Center, Houston, TX 77030, USA \\ * Correspondence: andersp@ccf.org or andersonmdphd@gmail.com; Tel.: +216-445-7140 or +216-308-2706
}

check for updates

Citation: Anderson, P.M.; Thomas, S.M.; Sartoski, S.; Scott, J.G.; Sobilo,

K.; Bewley, S.; Salvador, L.K.;

Salazar-Abshire, M. Strategies to Mitigate Chemotherapy and Radiation Toxicities That Affect Eating. Nutrients 2021, 13, 4397. https://doi.org/10.3390/ nu13124397

Academic Editor: Sadia Afrin

Received: 23 November 2021 Accepted: 6 December 2021

Published: 8 December 2021

Publisher's Note: MDPI stays neutral with regard to jurisdictional claims in published maps and institutional affiliations.

Copyright: (c) 2021 by the authors. Licensee MDPI, Basel, Switzerland. This article is an open access article distributed under the terms and conditions of the Creative Commons Attribution (CC BY) license (https:/ / creativecommons.org/licenses/by/ $4.0 /)$.

\begin{abstract}
Background: Cancer and its therapy is commonly associated with a variety of side effects that impact eating behaviors that reduce nutritional intake. This review will outline potential causes of chemotherapy and radiation damage as well as approaches for the amelioration of the side effects of cancer during therapy. Methods: Information for clinicians, patients, and their caregivers about toxicity mitigation including nausea reduction, damage to epithelial structures such as skin and mucosa, organ toxicity, and education is reviewed. Results: How to anticipate, reduce, and prevent some toxicities encountered during chemotherapy and radiation is detailed with the goal to improve eating behaviors. Strategies for health care professionals, caregivers, and patients to consider include (a) the reduction in nausea and vomiting, (b) decreasing damage to the mucosa, (c) avoiding a catabolic state and muscle wasting (sarcopenia), and (d) developing therapeutic alliances with patients, caregivers, and oncologists. Conclusions: Although the reduction of side effects involves anticipatory guidance and proactive team effort (e.g., forward observation, electronic interactions, patient reported outcomes), toxicity reduction can be satisfying for not only the patient, but everyone involved in cancer care.
\end{abstract}

Keywords: outpatient chemotherapy; nausea; anti-emetics; catabolic state; sarcopenia; sterotactic body radiotherapy (SBRT); therapeutic alliance; cancer treatment side effects

\section{Introduction}

Cancer remains a major public health problem in North America [1-3] and world-wide with $>10$ million deaths/year attributable to cancer [4]. What is feared by both patients and their caregivers is toxic therapy that may or may not be effective and makes eating a difficult and unpleasant experience especially when it is needed most. The proliferation of internet information (and some misinformation) along with very common use of dietary supplements shows how patient and caregivers perceive the life-or-death nature of cancer not only as very serious, but also quite worthy of extra time and effort to improve wellbeing. Furthermore, patient/caregiver time away from work or school coupled with high costs of cancer therapy also make cancer emotionally and financially toxic [5-13].

State-of-the-art cancer therapy utilizes advanced surgery and complex systemic treatments (chemotherapy combinations and/or radiation) for this often life-threatening condition. Organizations such as the Multinational Association for Supportive Care in Cancer (MASCC), the European Society of Clinical Oncology (ESMO), the American Society of 
Clinical Oncology (ASCO), and the National Comprehensive Cancer Network (NCCN) have provided guidelines to help with information and education about chemotherapy and radiation induced mucositis, nausea and vomiting [14-21].

Weighing indications, risks, and alternatives to achieve the highest benefit with lowest toxicity (i.e., high therapeutic index) is the current dynamic of cancer treatment for each person. Individual differences in cancer therapy tolerance are especially broad for the very young (infants and toddlers) and older (geriatric) persons. Chemotherapy drugs (Table 1) and radiation (Table 2) affect cancer cells and normal tissue differently. How cancer and its therapy can affect eating behaviors and contribute to toxicity in a complex, bidirectional manner is illustrated in Figure 1. Patient education about chemotherapy drugs and radiation often includes long and sometimes very confusing lists of potential side effects. A more organized approach is to review dose, schedule, drug combinations, and/or radiation with overlapping and non-overlapping toxicities in the context of common, less common and rare, as well as immediate, delayed, and long-lasting toxicity to normal tissues. Specialized oncology pharmacists coupled with tools such as hand-outs found on chemocare.com and Children's Oncology Group can provide patients and families a manner to organize this highly specialized information.

Table 1. Chemotherapy regimen variables to kill cancer cells with better normal tissue tolerance.

\begin{tabular}{|c|c|c|}
\hline Chemotherapy Regimen & Effect on Normal Tissue & Tumor Versus Normal Tissue Consideration(s) \\
\hline Dose & $\begin{array}{l}\text { Side effects against a normal tissue (for } \\
\text { example, production of platelets by bone } \\
\text { marrow) are dose-limiting }\end{array}$ & $\begin{array}{l}\text { An optimal biologic dose (OBD) instead of the } \\
\text { maximally tolerated dose (MTD) may facilitate } \\
\text { normal tissue healing. An area under the curve } \\
\text { (AUC) strategy with oral dosing or continuous } \\
\text { infusion can decrease toxicity of some drugs } \\
\text { (e.g., cyclophosphamide or ifosfamide }[22,23] \text { ) }\end{array}$ \\
\hline $\begin{array}{l}\text { Mechanisms of action against } \\
\text { dividing cells }\end{array}$ & $\begin{array}{l}\text { Marrow, mouth, esophagus, intestines, } \\
\text { and skin are easily damaged } \\
\text { by chemotherapy }\end{array}$ & $\begin{array}{l}\text { Chemotherapy guidelines should allow adequate } \\
\text { tissue recovery before administration of the next } \\
\text { cycle allowing for improvement in blood counts, } \\
\text { mucositis, diarrhea, and skin) }\end{array}$ \\
\hline Biodistribution & $\begin{array}{l}\text { Oral mucosa and skin blood flow are } \\
\text { temperature dependent }\end{array}$ & $\begin{array}{l}\text { Oral cryotherapy can reduce mucositis [24-27] } \\
\text { Cold packs may decrease hand-foot erythroderma }\end{array}$ \\
\hline Drug metabolism & $\begin{array}{l}\text { Elimination and inactivation of } \\
\text { chemotherapy drugs vary between } \\
\text { tissues and persons }\end{array}$ & $\begin{array}{l}\text { Dose adjustment if excessive toxicity is seen } \\
\text { Facilitate detoxification by normal cells } \\
\text { (e.g., improve glutathione [28-30]) }\end{array}$ \\
\hline Protective drugs & $\begin{array}{l}\text { Can reduce damage to normal tissues to } \\
\text { mitigate or avoid significant short-term } \\
\text { or long-term side effects }\end{array}$ & $\begin{array}{l}\text { Mesna to protect the bladder from acrolein } \\
\text { metabolite after cyclophosphamide or ifosfamide } \\
\text { Dexrazoxane to protect heart from doxorubicin } \\
\text { Dexamethasone to prevent taxane reactions } \\
\text { Leucovorin to rescue from methotrexate }\end{array}$ \\
\hline Drug combinations & $\begin{array}{l}\text { Combinations of chemotherapy drugs } \\
\text { can be more toxic to organs and tissue } \\
\text { than a single agent }\end{array}$ & $\begin{array}{l}\text { Chemotherapy combinations with } \\
\text { non-overlapping toxicities and alternating } \\
\text { regimens to achieve less toxicity are often used }\end{array}$ \\
\hline
\end{tabular}

Cumulative organ toxicity can occur with repeated cycles of chemotherapy (e.g., cochlea [31], kidney, heart, lung, "chemobrain"). If an oncology team orders the next chemotherapy cycle before normal marrow cells recover (for example, inadequate red cell, white cell, or platelet recovery), the next cycle may require longer recovery time because the lowest point (nadir) becomes lower. However, if an oncology team waits too long to start the next chemotherapy cycle, cancer cells may proliferate or spread while waiting for normal tissue recovery. Thus, each chemotherapy cycle should kill more cancer cells than are able grow back while allowing normal tissues to heal between cycles. 
Table 2. Radiation damage associations: variables to damage tumor with less normal tissue side effects.

\begin{tabular}{|c|c|c|}
\hline Damage Association & Variable & Tumor Versus Normal Tissue Consideration(s) \\
\hline Fraction dose size & Amount of radiation energy per dose & $\begin{array}{c}\text { Larger fractions are biologically more effective against } \\
\text { tumors than normal cells }\end{array}$ \\
\hline Schedule & $\begin{array}{l}\text { One-time, daily for } 1 \text { week, or daily (e.g., M-F) for } \\
\qquad 3 \text { to } 5 \text { weeks }\end{array}$ & $\begin{array}{c}\text { Time between radiation doses allows both tumor and } \\
\text { normal tissue repair }\end{array}$ \\
\hline $\begin{array}{l}\text { Tumor } \\
\text { radiosensitivity }\end{array}$ & $\begin{array}{c}\text { Some cancers (e.g., Wilms tumor, lymphomas) are } \\
\text { very radiosensitive. Other cancers (e.g., carcinomas, } \\
\text { brain tumors, sarcomas, metastases) can be more } \\
\text { difficult to kill with radiation. }\end{array}$ & $\begin{array}{l}\text { Smaller total dose is needed to treat some tumors with } \\
\text { curative intent. If a tumor is relatively radioresistant, } \\
\text { a combination of chemotherapy and radiation may work } \\
\text { better against tumor cells [32-34] }\end{array}$ \\
\hline Radiation particle & $\begin{array}{l}\text { Photons and electrons have less energy than protons } \\
\text { and alpha particles. More energy results in hard to } \\
\text { repair double strand DNA breaks in cancer cells }\end{array}$ & $\begin{array}{l}\text { Choice of the type of radiation often depends on normal } \\
\text { tissue nearby as well as the dose needed to treat }\end{array}$ \\
\hline $\begin{array}{l}\text { Precision of radiation } \\
\text { treatment plan }\end{array}$ & $\begin{array}{l}\text { Stereotactic body radiotherapy (SBRT) sterotactic } \\
\text { radiosurgery (SRS) and proton radiotherapy plans } \\
\text { are very precise. These require not only expensive } \\
\text { radiation machines, but a highly specialized } \\
\text { radiation physicist and oncologist time and effort for } \\
\text { each individualized treatment plan }\end{array}$ & $\begin{array}{l}\text { Palliative radiation plans are less precise and use lower } \\
\text { doses for rapid treatment planning to reduce pain with } \\
\text { acceptable (low) damage to nearby tissue. Image guidance } \\
\text { provides more precise radiation treatment plans (more to } \\
\text { tumor and less to normal tissue) } \\
\text { Very precise SBRT, SRS, or proton plans may take } \\
\text { 1-2 weeks before the patient can start radiotherapy in } \\
\text { a manner that treats tumor and minimizes radiation to } \\
\text { nearby normal tissue }\end{array}$ \\
\hline
\end{tabular}

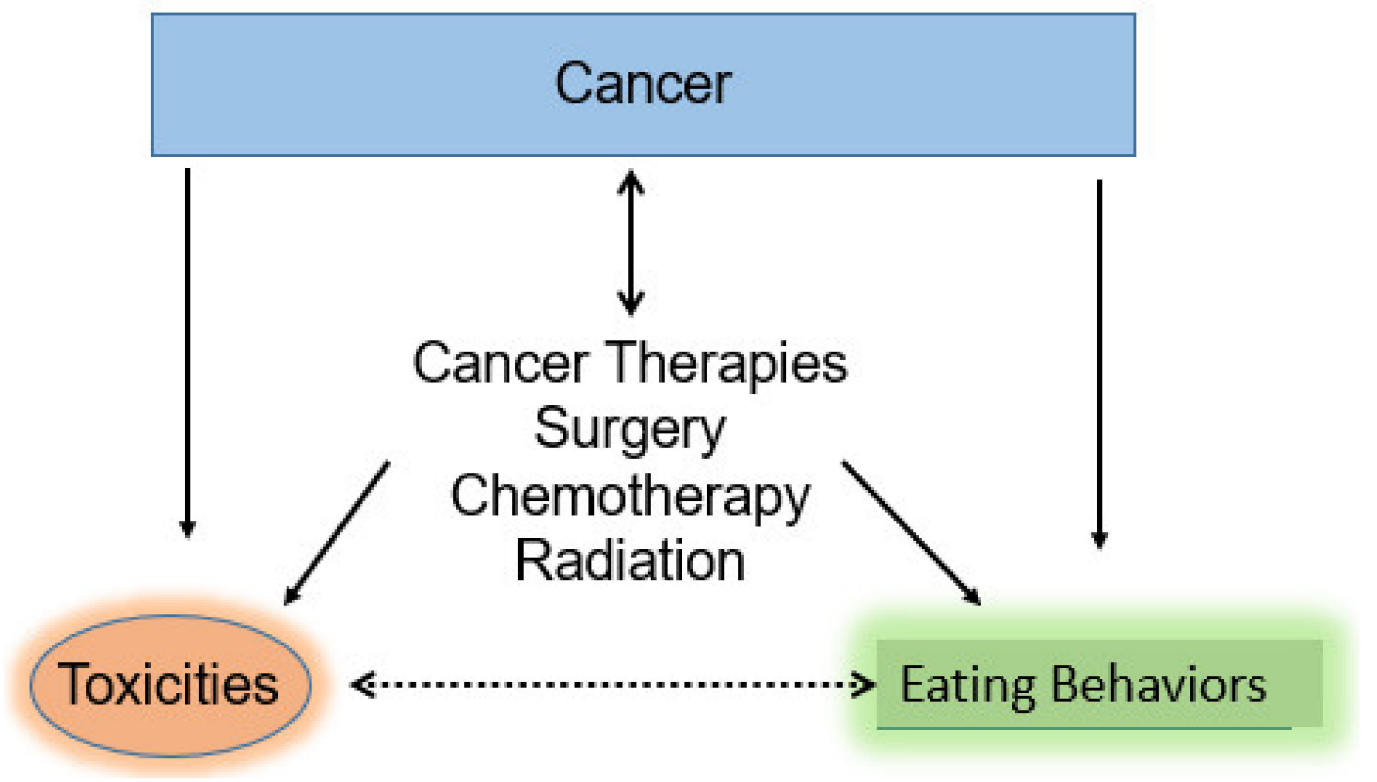

Figure 1. Bidirectional and complex nature of the three main cancer treatment modalities (surgery, chemotherapy, and radiation) on toxicities and eating behaviors. Complex interactions of therapy affect quantity and quality of nutrient intake and toxicities encountered when attempting to reduce or eliminate cancer cells.

Although oncology is a very scientific and evidence-based discipline with hundreds of thousands of studies for general and specific questions and common-sense consensus guidelines by experts to guide clinicians and patients [3,21], our ability to ameliorate toxicities and predict survival outcomes for an individual is limited. Estimates often are "guestimates" and vary with time and experience. Medical professionals and cancer patients alike believe toxicities are inevitable and general amelioration techniques are often overlooked. Difficulty eating and malnutrition during cancer therapy are common problems that can be assessed with many tools [35-51]. The challenge is to have an acceptable quality and quantity of nutrient intake with minimal toxicity without compromising effective cancer treatment. 
Complex and bidirectional interactions occur between cancer, therapy, toxicities, and eating behaviors (Figure 1). This article will review some mitigation strategies to organize patients and caregivers during virtual visits [52], hospitalizations, and outpatient clinic discussions with oncologists, nurse practitioners (NP), physician assistants (PA), navigators, pharmacists, nurses, and dietitians. Nursing educators and oncology navigators are relatively new positions in the oncology team who can multiply the effectiveness of education efforts by helping not only individual patients, but also educate inpatient and outpatient oncology nurses. Additionally, quality and continuous improvement efforts can facilitate creating systems in oncology clinics and hospitals to foster health literacy and to adapt and adopt patient and family-centered best practices [53-57].

\section{Review of Strategies to Improve Eating Behaviors While Receiving Chemotherapy and/or Radiation}

One of the most common questions of cancer patients and caregivers is "what should I eat or drink to improve my situation?" [58] This topic is very important but sometimes relatively neglected because of many time-consuming tasks associated with accurately prescribing chemotherapeutics and radiation therapy accurately and on time [58-65]. Fortunately, dietitians with oncology experience can provide tools and information to patients regarding food choices, eating behavior, and issues including poor oral intake and intermittent fasting when patients get chemotherapy and/or radiation [66-68]. Not only infusion nurses, but also oncology educators and navigators can use patient and caregiver feedback to increase dietitian consultation for cancer patients. Malnutrition in cancer patients is a common problem. There are many indices and tools to define malnutrition, cachexia, and sarcopenia [35-51,62,69-77]. Although weight loss from the time of diagnosis is one measure, the quantity and quality of food in the diet and information from the patient generated subjective global assessment (PG-SGA) tool can provide more specific information [35,36,45,51,62,66,69-73,78-80].

Nevertheless, weight stability, weight loss, or weight gain is what the oncologist, oncology NP or PA needs when calculating and confirming chemotherapy drug dosage and is imperative for safety prior to prescribing chemotherapy. Typically, unless a $>10 \%$ change is noted, no changes are required in chemotherapy dose. However, $5-10 \%$ body weight loss usually requires redoubled efforts to improve weight. If weight gain is real, which sometimes happens in children during leukemia chemotherapy, dose is increased. If a gain is "artificial" (e.g., fluid retention or ascites), chemotherapy doses are not increased. If there is $>10 \%$ weight loss, then additional nutrition support is given via enteral feeding device (e.g., NG or G-tube), or total parenteral nutrition (TPN) intravenously if unable to feed enterally. In this circumstance, chemotherapy dosage is usually decreased. Higher level nutritional intervention can also reduce or avoid chronic nausea unrelated to chemotherapy administration that is associated with superior mesenteric artery syndrome with omental and mesenteric fat loss from chronic inadequate nutrients. A reasonable goal of the cancer patient and family should be to optimize nutrition with less effort so the positive social aspects of meals together and nutrient intake are enjoyable (Figure 2). Quality metrics in the hospital and oncology clinic can assist programs to achieve less toxicity and better resource utilization both routinely [81] and when efforts like TPN $[49,82,83]$ and hospitalization [7,12] are utilized.

\subsection{Nausea as a Source of Poor Appetite: Approaches to Reduce Nausea}

Unfortunately, a common side effect of chemotherapy and radiation is nausea and/or vomiting $(\mathrm{N} / \mathrm{V})$. In the past 25 years, major advances in nausea and vomiting reduction from chemotherapy and/or radiation therapy have improved this situation. These include the following: common use of selective serotonin receptor (5-HT3 also known as 5HT) antagonists for immediate N/V, neurokinin receptor antagonists (aprepitant and fosaprepitant) for delayed nausea, and the recognition of corticosteroids and olanzapine in front-line anti-emetic regimens for chemotherapy and radiation [19,21,84-88]. Although N/V from chemotherapy and/or radiation remains common, there are many effective strategies to 
ameliorate $\mathrm{N} / \mathrm{V}$ and improve eating behaviors during chemotherapy and radiation as detailed in Table 3.

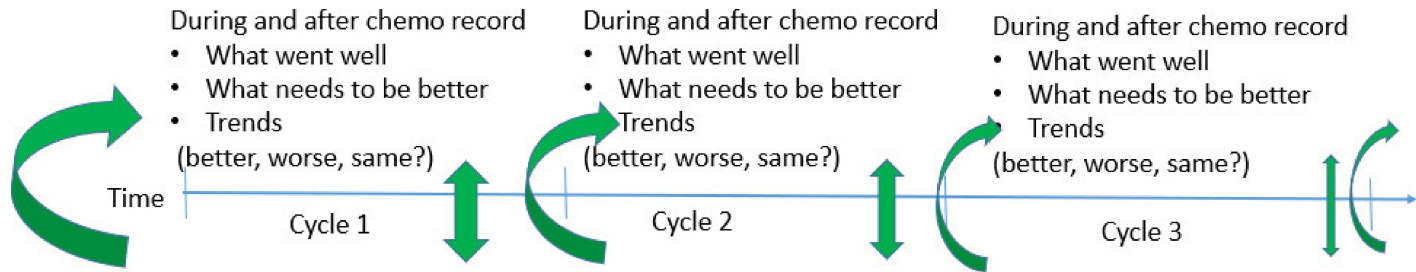

Planning review (each cycle)

- chemo schedule

- current weight

- anti-emetics

- diet principles

- how to communicate with team
Review symptom control and weight trend with patient and caregiver and adjust before next chemo cycle

- anti-emetics (scheduled + prn)

- diet recommendations

- how to communicate with team
Review symptom control and weight trend with patient and caregiver and adjust before next chemo cycle

- anti-emetics (scheduled + prn)

- diet recommendations

- how to communicate with team

Figure 2. Proactive, adaptive, eclectic, and flexible approach to continuously improving symptoms and eating so each chemotherapy cycle gets better, and daily activities become more normal with fewer adjustments needed.

Table 3. Causes of nausea and vomiting $(\mathrm{N} / \mathrm{V})$, reduction agents, and mitigation strategy issues.

\begin{tabular}{|c|c|c|}
\hline $\begin{array}{c}\text { Cancer Therapy N/V Cause } \\
\text { and Associations }\end{array}$ & $\begin{array}{l}\text { Anti-Emetic Agents and Mechanisms of } \\
\text { Action: Generic Name (Brand Name) }\end{array}$ & $\begin{array}{l}\text { Strategy, Some Practical Considerations, } \\
\text { and References }\end{array}$ \\
\hline $\begin{array}{l}\text { Immediate } \mathrm{N} / \mathrm{V} \text { from chemotherapy } \\
\text { agents: chemoreceptor } \\
\text { trigger zone }\end{array}$ & $\begin{array}{l}\text { Selective serotonin receptor (5HT) antagonists: } \\
\text { - } \quad \text { Ondansetron (Zofran) } \\
-\quad \text { Granisetron (Kytril, Sancuso) } \\
\quad \text { Palonosetron (Aloxi) }\end{array}$ & $\begin{array}{l}\text { MASCC + ASCO anti-emetic guidelines for } \\
\text { chemotherapy and radiation }[19,21] \text {; ondansetron has } \\
\text { more drug interactions. Granisetron is an oral or } \\
\text { transdermal patch. Palonosetron is IV, has fewer drug } \\
\text { interactions and longest half-life }[84,86,87] \text {. }\end{array}$ \\
\hline Dysmotility & $\begin{array}{l}\text { Dopamine agonists: } \\
\text { - } \quad \text { Metoclopramide (Reglan) } \\
\text { - } \quad \text { Prochlorperazine (Compazine) }\end{array}$ & $\begin{array}{l}\text { Use with caution in children. Dopamine agonists } \\
\text { can cause extrapyramidal symptoms including } \\
\text { dystonic reactions. }\end{array}$ \\
\hline Inflammation & $\begin{array}{l}\text { Corticosteroids act on both immune cells and } \\
\text { tumor microenvironment: } \\
\text { - } \quad \text { Dexamethasone (Decadron) } \\
\text { - } \quad \text { Methyprednisolone (Medrol) } \\
\text { - } \quad \text { Prednisone } \\
\text { Hydrocortisone }\end{array}$ & $\begin{array}{l}\text { Excellent for 1-7 days; high-doses can increase appetite } \\
\text { and eating, but cannot use long term because of } \\
\text { chronic issues, including: infection, appearance, skin } \\
\text { thinning, blood pressure, diabetes, osteoporosis and } \\
\text { avascular necrosis of shoulder, hip, and knee joints }\end{array}$ \\
\hline $\begin{array}{l}\text { Delayed N/V: Many hours to days } \\
\text { after starting chemotherapy }\end{array}$ & $\begin{array}{l}\text { Neurokinin receptor antagonists: } \\
\text { - } \quad \text { Aprepitant (Emend) oral } \\
\text { - } \quad \text { Fosaprepitant (Ivemend in EU) }\end{array}$ & $\begin{array}{l}\text { Few drug interactions; especially effective with } \\
\text { cisplatin. Can give fosaprepitaint intravenously on } \\
\text { days } 1 \text { and } 4 \text { of each 5-day cycle }\end{array}$ \\
\hline Anticipatory N/V & $\begin{array}{l}\text { Help change context of N/V } \\
\text { - } \quad \text { Lorazepam (Ativan) } \\
\text { Diphenhydramine (Benadryl) }\end{array}$ & $\begin{array}{l}\text { Change environment or routine } \\
\text { Take meds before coming to clinic } \\
\text { Oral or IV possible; some sedation is associated with } \\
\text { these agents which may be an undesirable side effect } \\
\text { especially if it impedes nutritional intake }\end{array}$ \\
\hline Sleep deprevation & $\begin{array}{l}\text { Promote routine sleep } \\
\text { - } \quad \text { Melatonin } \\
\text { - } \quad \text { Olanzapine (Zyprexa) } \\
\text { Diphenhydramine (Benadryl) }\end{array}$ & $\begin{array}{l}\text { At bedtime } \\
\text { melatonin } 2-10 \mathrm{mg} \text { per day } \\
\text { olanzapine may also help mood } \\
\text { sedating }\end{array}$ \\
\hline Decreased appetite & $\begin{array}{l}\text { Central acting } \\
\text { - } \quad \text { Tetrahydrocannabinol (THC) } \\
\text { - } \quad \text { Medroxyprogesterone (Megace) }\end{array}$ & $\begin{array}{l}\text { Oral before meals } \\
\text { THC also has antiemetic activity } \\
\text { Both pills and liquid available }\end{array}$ \\
\hline Motion sickness & Scopolamine (Transderm Scop) & Patch for 3 days \\
\hline Multiple causes & $\begin{array}{l}\text { Anti-emetic combinations often more effective } \\
\text { than single agents }\end{array}$ & MASCC, ESMO, ASCO, and NCCN guidelines [14-21] \\
\hline
\end{tabular}




\subsection{Proactive Approaches to Toxicity Reduction for Better Eating Behaviors (Forward Observation)}

Figure 2 illustrates a proactive and adaptive approach towards nausea and vomiting reduction during sequential chemotherapy cycles. This involves shared decision making and understanding chemotherapy dosing and schedule using current weight trends, side-effect profiles, and toxicity prevention strategies through adaptation and continuous improvement. Continuous improvement requires the patient and caregivers providing the oncology team with high quality information about what was effective during a chemotherapy cycle and what could be improved in the next cycle. This information can then guide adjustments with each cycle such as the dose or schedule, and the addition or substitution of different anti-emetic agents, and dietary modifications. An adaptable and eclectic approach avoids "running the same play" resulting in the same or worse toxicity and possibly having increasingly worse eating behaviors. The goal is to help the patient and family avoid repetitive and/or cumulative issues with $\mathrm{N} / \mathrm{V}$ and reduced appetite during chemotherapy so that eating becomes predictably better and enjoyable. Meals are then not major issues, but rather a source of companionship, social interaction, and improved well-being.

\subsection{Mucosal and Skin Injury}

Another problem from chemotherapy and radiation is damage to the mucosal lining cells of the mouth, esophagus, stomach, intestines, and rectum (mucositis) [14,16-18,20,89-95]. The reduction in stomatitis (mouth sores), esophagitis, enteritis, and/or proctitis (rectal pain) caused by chemotherapy and radiation will improve eating behavior and nutrient choices during cancer therapy. Mucositis is a common problem and affects a variety of tissues not only from the toxicity of chemotherapy drugs, but also from radiation affecting tissue near the tumor target, too. Mucosal injury, especially to the mouth and GI tract, is often painful but transient.

Unfortunately, sometimes long-lasting toxicities occur (e.g., neuropathy, cardiotoxicity, esophageal or intestinal stricture/dysfunction long after completion of chemotherapy and/or radiation), therefore, efforts to rate treatment intensity and to mitigate cancer therapy toxicities are important to long-term health [96]. Many mucositis prevention strategies and treatments have been evaluated and have been summarized by MASCC/ISOO guidelines $[14,16-18,20,89]$. Table 4 lists specific agents and mucositis reduction strategies. Table 5 details agents and causes that contribute to epithelial toxicities of chemotherapy and/or radiation and some mitigation strategies. Physical therapy (PT) and occupational therapy (OT) can be helpful in maintaining mobility and developing strategies to accomplish activities of daily living including eating as part of education about long-term health in cancer patients.

Table 4. Mouth sores, esophagitis, and enteritis: agents, injury type, and reduction during cancer therapy.

\begin{tabular}{ccc}
\hline Agent & Type of Injury & Reduction Strategies \\
\hline Melphalan & High dose alkylator (peak effect) & $\begin{array}{c}\text { Cryotherapy (ice chips) [24-27] } \\
\text { Keratinocyte growth factor (palifermin) [97-101] }\end{array}$ \\
\hline Gemcitabine & Cytotoxic injury of mucosal cells & $\begin{array}{c}\text { A 30 min infusion is less toxic than a 90 min infusion. } \\
\text { Avoid daily dosing. Often used weekly } \times \text { 2 weeks } \\
\text { (day 1, day 8) and then 1 week off }\end{array}$ \\
\hline 5-Flurouracil & Cytotoxic injury to mouth & Cryotherapy; change schedule \\
\hline Doxorubicin & Cytotoxic injury, radiation recall & $\begin{array}{c}\text { Use dexrazoxane, then a short infusion of } \\
\text { doxorubicin, instead of continuous infusion to } \\
\text { reduce heart injury; to reduce mucositis use } \\
\text { glutamine + trehalose (Healios, [89]) }\end{array}$ \\
\hline $\begin{array}{c}\text { Mammalian target of rapamycin } \\
\text { (mTOR) inhibitors }\end{array}$ & $\begin{array}{c}\text { Cytotoxic injury by sirolimus, } \\
\text { temsirolimus, everolimus }\end{array}$ & $\begin{array}{c}\text { Follow blood levels and adjust dose; } \\
\text { use glutamine + trehalose [89] }\end{array}$ \\
\hline $\begin{array}{c}\text { Vascular endothelial growth factor } \\
\text { (VEGF) inhibitors: bevacizumab, } \\
\text { pazopanib, cabozantinib, regorafenib }\end{array}$ & $\begin{array}{c}\text { Less of an ability to form new blood vessels: } \\
\text { wounds and radiation injured tissues } \\
\text { heal slowly }\end{array}$ & $\begin{array}{c}\text { Dose reduction or drug holiday utilizing intermittent } \\
\text { dosing of oral agents (e.g., three weeks on then } \\
\text { one week off) }\end{array}$ \\
\hline
\end{tabular}


Table 4. Cont.

\begin{tabular}{|c|c|c|}
\hline Agent & Type of Injury & Reduction Strategies \\
\hline Irinotecan & $\begin{array}{l}\text { Active metabolite of irinotecan in the intestinal } \\
\text { lumen, SN-38, causes intestinal mucosa injury }\end{array}$ & $\begin{array}{l}\text { Reduction of immediate cramping, diarrhea, and GI } \\
\text { upset: loperamide }+/- \text { atropine. For intermediate } \\
\text { and delayed diarrhea octreotide and/or } \\
\text { glutamine }+ \text { trehalose (Healios [89]). If eating solid } \\
\text { food is difficult, liquid nutritional supplements } \\
\text { can be helpful }\end{array}$ \\
\hline Yeast & $\begin{array}{l}\text { Broad spectrum antibiotics reduce normal } \\
\text { bacterial flora }\end{array}$ & $\begin{array}{c}\text { Anti-fungal antibiotics, yogurt, kefir; } \\
\text { limit anti-bacterial antibiotics unless suspected or } \\
\text { known infection(s) }\end{array}$ \\
\hline Radiation & $\begin{array}{l}\text { Harms rapidly dividing cells in the renewing } \\
\text { tissues (crypts) lining the mouth, esophagus, } \\
\text { intestines, rectum }\end{array}$ & $\begin{array}{l}\text { Protein to heal and/or glutamine + trehalose; review } \\
\text { radiation plan (dose/schedule) to allow some } \\
\text { healing (e.g., weekends off); boost radiation to tumor } \\
\text { volume only. Keep skin and mucosal surfaces clean. } \\
\text { If whole abdominal radiation therapy (WART): } \\
\text { g-tube for additional enteral nutrition }\end{array}$ \\
\hline
\end{tabular}

Radiation recall is a rash after chemotherapy resembling a sunburn only in skin previous exposed to radiation (in-field). Radiation recall rash can also give clues about damage to nearby structures beneath the skin that are also in the radiation field (e.g., mouth, esophagus, stomach, intestines) that can affect eating. It is possible to decrease skin toxicity with creams such as Eucerin, Glucan-Pro or topical corticosteroids. Furthermore, less skin toxicity can improve sense of well-being and feeling "normal", thereby facilitating more exercise and activity and improving eating behavior. Table 5 details some strategies to reduce epithelial and skin toxicity and to promote wound healing.

Table 5. Reducing chemotherapy and radiation damage in epithelial tissues (skin and mucosa).

\begin{tabular}{|c|c|c|}
\hline Cause of Damage & Type of Injury and Consequence(s) & Reduction Strategies \\
\hline Radiation & $\begin{array}{l}\text { Single and double-stranded DNA breaks: } \\
\text { cell death }\end{array}$ & $\begin{array}{l}\text { Anticipatory guidance that damage may last longer } \\
\text { than radiation treatment. Glutamine seems protective } \\
\text { for some tissues, especially intestines }[30,89,102-105]\end{array}$ \\
\hline $\begin{array}{c}\text { Radiotherapy (RT) or surgery and } \\
\text { VEGF inhibitors }\end{array}$ & $\begin{array}{l}\text { Tissue may heal slowly after VEGF inhibitors } \\
\text { due to decrease in vasculature }\end{array}$ & $\begin{array}{c}\text { Use the oral tyrosine kinase inhibitor (TKI) with } \\
\text { shorter half-lives so if there are symptoms, these can be } \\
\text { stopped, and then restarted sooner (when the wound } \\
\text { or injury is improved) }\end{array}$ \\
\hline $\begin{array}{l}\text { Corticosteroids: prednisone } \\
\text { methylprednisolone dexamethasone }\end{array}$ & $\begin{array}{l}\text { Thinning of skin } \\
\text { Delayed wound healing } \\
\text { Increased risk of infections }\end{array}$ & $\begin{array}{l}\text { Use short 1-5 day pulses. If prolonged use, then taper } \\
\text { to hydrocortisone in physiologic doses (e.g., } 15 \text { to } \\
\qquad 20 \mathrm{mg} \text { am and } 10 \mathrm{mg} \mathrm{pm})\end{array}$ \\
\hline Opiates & $\begin{array}{l}\text { Slower GI motility causes nausea, constipation, } \\
\text { hard stool with rectal fissures and perirectal } \\
\text { inflammation may recur with each cycle of } \\
\text { chemotherapy when patient may experience } \\
\text { tissue damage and subsequent infection due to } \\
\text { low neutrophil counts }\end{array}$ & $\begin{array}{l}\text { Increase liquid in diet and physical activity as tolerated } \\
\text { for patient. When appropriate consults to PT/OT. Kefir, } \\
\text { stool softeners such as docusate, lactulose, } \\
\text { polyethylene glycol powder } 3350 \text { (MiraLax), and senna } \\
\text { can be helpful. Use of a hand-held shower and baby } \\
\text { wipes or cotton-balls with lotion may clean rectal } \\
\text { tissues with less damage }\end{array}$ \\
\hline Total parenteral nutrition (TPN) & $\begin{array}{l}\text { Prolonged use is associated with villous } \\
\text { atrophy of intestine lining and liver toxicity }\end{array}$ & $\begin{array}{l}\text { Some trophic enteral nutrition is needed to increase } \\
\text { absorptive surface of intestines and to avoid liver toxicity }\end{array}$ \\
\hline $\begin{array}{l}\text { Abdominal surgery then } \mathrm{RT} \text { to } \\
\text { abdomen especially whole abdominal } \\
\text { radiotherapy (WART) }\end{array}$ & $\begin{array}{l}\text { Less GI motility post-op delays eating } \\
\text { increases radiation enteritis. Effects of } \\
\text { radiation can cause future small } \\
\text { bowel obstruction }\end{array}$ & $\begin{array}{l}\text { Gastrostomy tube (g-tube) to facilitate hospital } \\
\text { discharge and eating sooner with better enteral } \\
\text { nutrition before, during, and after whole abdominal } \\
\text { radiotherapy (WART). PT/OT and dietitian consults }\end{array}$ \\
\hline $\begin{array}{l}\text { Head and neck RT } \\
\text { C-spine or T-spine RT } \\
\text { (with or without } \\
\text { concurrent chemotherapy) }\end{array}$ & $\begin{array}{l}\text { Often associated with severe mucositis } \\
\text { including mouth sores } \\
\text { (stomatitis) and oropharyngeal and } \\
\text { esophageal mucositis }\end{array}$ & $\begin{array}{c}\text { MASCC guidelines }[15-17,20] \text {. Pain medicine before } \\
\text { eating and OT consult; glutamine + trehaose } \\
\text { suspension (Healios) swish } 10 \mathrm{~s} \text { then spit } \\
\text { or swallow [89] }\end{array}$ \\
\hline $\begin{array}{l}\text { High-dose chemotherapy }+/-\mathrm{RT} \\
\text { (preparative regimens for bone } \\
\text { marrow transplant (BMT) }\end{array}$ & $\begin{array}{l}\text { Very high incidence of mucositis. Extra } \\
\text { inflammation may predispose to graft versus } \\
\text { host disease (skin, mouth, and GI toxicities). } \\
\text { Toxicities can cause eating and activity issues }\end{array}$ & $\begin{array}{l}\text { Palifermin [97] and/or a very high level of supportive } \\
\text { care (TPN, G-tube or NG tube) }[27,85,90,106-108] \text {. } \\
\text { PT/OT and education to maintain "trophic" enteral } \\
\text { can be helpful. MASCC guidelines }[15-17,20]\end{array}$ \\
\hline
\end{tabular}

Hematologic toxicity from chemotherapy and radiation can adversely affect nutrient intake. Anemia caused by decreased production of red blood cells by the bone marrow as a direct effect of chemotherapy and radiation can cause fatigue. Sometimes iron deficiency from blood loss or inadequate iron intake is seen even before anemia becomes apparent. 
Iron deficiency can also cause a protein losing enteropathy which makes iron absorption more difficult. Fortunately, iron depletion or deficiency can be corrected easily and quickly (1-3 days) using intravenous iron supplementation (e.g., iron sucrose, Venofer). Red cell or platelet transfusions are sometimes needed to support patients with chemotherapy associated severe anemia or low platelets (thrombocytopenia) or during radiation to keep tissue oxygenation high and decrease risk of bleeding. Patients will often feel much better and have less fatigue if transfused at a medium low hemoglobin (e.g., $\mathrm{Hb} 8$ ) and/or downward trending instead of waiting until anemia becomes quite severe.

Discussion of indications, risks, and alternatives and "using patient as their own control" to decide on transfusion or growth factor thresholds are common practices in oncology. Growth factors can increase the neutrophil type of white cell numbers, decrease infection risk and keep chemotherapy cycles on time. Granulocyte colony stimulating factor (G-CSF) is commonly used in North America and Europe. Growth factors for red cell production (e.g., erythropoietin or darbopoietin) and platelet production (romiplostim or eltrombopag) are used less often, but also can be effective. Better neutrophil counts are associated with better mucosal healing, too. Finally, lymphopenia, a common side effect of chemotherapy and radiation is associated with not only increased infection risks (e.g., pneumocystis pneumonia), but also decreased survival [109]. More rapid recovery of lymphocytes is associated with improved survival [109-112]. Since the metabolic fuel for lymphocytes is glutamine, a diet with adequate protein may be beneficial and outweigh any deleterious effects of glutamine supplementation such as an energy source of tumor cells [89]. Since glutamine is always the highest amino acid in the blood and subject to homeostatic regulation (muscle will breakdown if there is not enough protein in the diet) to maintain plasma glutamine levels, glutamine and or protein supplementation should be considered as a means to provide local and systemic anabolic effects.

\subsection{Deconditioning and Fatigue}

Deconditioning associated with the loss of muscle mass (sarcopenia) is another potential consequence of chemotherapy and radiation toxicity. First, voluntary or involuntary confinement to a hospital room can severely reduce activity. Well-meaning activity limits by caregivers to limit falls can result in fewer steps and a profoundly sedentary life-style for cancer patients (e.g., less activities of daily living such as shopping, dining out, mowing the lawn, washing clothes, cleaning, doing the dishes for outpatients). Once deconditioning occurs, routine activities become increasingly difficult. To achieve a Karnofsky performance scale (KPS) level of $100 \%$, activities of daily living including predictable eating behaviors and walking more should be actively encouraged. Sometimes a step counter device (e.g., Fit-bit or Apple watch) can provide meaningful and accurate feedback about activity level and help avoid deconditioning. Ensuring that consultations are made with our allied health partners (such as physical therapy, occupational therapy and when working with pediatrics to child life therapy) also serves to promote regular physical activity and avoid deconditioning that so often accompanies chemotherapy and radiation therapy toxicity. Consultations to our behavioral science partners such as psychology and psychiatry should also be made to combat fatigue associated with depressed mood that may result from confinement to the hospital, cancer treatment, or from the diagnosis of cancer in an individual.

If possible, cancer patients should discuss advantages and limitations of outpatient versus inpatient chemotherapy regimens with the oncology team; outpatient chemotherapy often results in better eating behavior and more activity with less deconditioning and fatigue. Sarcopenia (less muscle mass) is probably related to both deconditioning (if you do not use it, you lose it) as well as inadequate calories and protein. Less sarcopenia has been associated with fewer fevers associated with neutropenia and improved survival $[75-77,113]$. 


\subsection{Improved Information}

When professionals make decisions, the variability of skills needed, and tasks required, seems impossibly complex and full of noise. However, when patients and caregivers make use of professionals and networks of people with many different and complementary skill sets, this eclectic approach can help to get the best information from a variety of sources. The author has termed this activity developing therapeutic alliances [52,114]. Quality specialists, nurse educators, oncology navigators, nurse practitioners, physician assistants, and dietitians with oncology experience are especially skilled at facilitating therapeutic alliances and family-centered care $[13,53-56,96,114,115]$. Table 6 illustrates some aspects of developing therapeutic alliances to anticipate and ameliorate chemotherapy and radiation toxicity and improve the journey of receiving cancer therapy.

Table 6. Therapeutic alliances of cancer patients to obtain information and support.

\begin{tabular}{ccc}
\hline Oncology Professionals & Others in the Clinic and Hospital & Community Resources \\
\hline Medical Oncologist & Dietitian (nutritionist) & Primary caregiver \\
Pediatric Oncologist & Social worker & Other family \\
Radiation Oncologist & Psychological support (coping skills) & Peer support (disease-specific groups) \\
Oncology Surgeon & Physical therapy (PT) & Facebook and other internet sites \\
Nurse Educator & Occupational therapy (OT) & On-line consults \\
Oncology Pharmacist & Art therapy & Insurance case manager \\
Oncology Navigator & Music therapy & Faith community \\
Oncology Nurse Practioner & Scheduling & School support \\
Oncology Physician Assistant & Lab (e.g., phlebotomy) personnel & Employee support \\
Chemotherapy Nurse & Radiology personnel & Neighbors \\
Virtual Oncologist [52] & Quality teams & Child life specialists
\end{tabular}

\section{Discussion}

Chemotherapy and radiation toxicity reduction should result in better eating and less sarcopenia $[47,74-78,113,116-118]$. This complex and often bidirectional interaction (Figure 1) may also translate into fewer episodes of fever and neutropenia and improved survival [75-77]. Lymphopenia (low lymphocyte counts) is associated with radiation and worse survival [109]. Better eating may also improve immune function by supplying glutamine for lymphocytes and better immune function [119-122]. Finally, nutrient intake may have some cancer prevention properties $[123,124]$ and help with glutathione production to ameliorate toxicity $[28,29]$ and to reduce some chemotherapy and radiation associated toxicity [30,103-105,125-127]. Since cancer is more prevalent in older adults, the problem of increased toxicity associated with poor eating in sarcopenic, frail, older patients with co-morbidities and polypharmacy can be challenging [74,77,118,128-132]. Use of the Geriatric Nutrition Risk Index (GNRI) or Mini-Nutritional Assessment (MNA) tools [133-135] and patient reported outcomes (PRO) such as the PG-SGA [69-73,136-140] could help to predict risk and trigger more timely interventions to address eating behaviors, malnutrition, cachexia, and sarcopenia in this particularly vulnerable, high-risk population. A recent study showed a proactive team approach which included an oncologist, NP, social worker, $\mathrm{PT} / \mathrm{OT}$, pharmacist, and nutritionist resulted in the significant reduction of grade 3 or higher toxicities in older adults [141].

Obesity has become increasingly prevalent and is associated with the increased cancer risk and worse cancer outcomes [142-150]. Increased BMI can adversely affect response to agents such as VEGF inhibitors [146], endocrine therapy in breast cancer [144], hematologic chemotherapy toxicity in gynecologic cancer [142], and outcomes after SBRT for prostate cancer [147]. The occurrence of metabolic syndrome and poor glucose control in obese cancer patients can increase the risk of non-cancer death in survivors [151] and increase the susceptibility to infections including SARS-CoV-2 (COVID-19) [152-155]. Aerobic and resistance exercise are means to reduce sarcopenia in obese and non-obese can- 
cer patients $[145,156]$. Concepts of avoiding sarcopenia, reducing metabolic syndrome, and improving function and strength in obese cancer patients, as advocated by DieliConwright and others, can improve the quality of life while on therapy and in cancer survivors [145,148,156-165]. This involves education to neither lose too much weight nor gain a lot of weight, but to focus on staying active and strong. Aerobic and resistance exercise can improve the problem of sarcopenia and possibly mitigate expectations of worse outcomes in obese cancer patients [145,156-164].

Since patient eating behaviors are generally superior as an outpatient compared to inpatient, electronic patient-reported outcomes (ePRO) [69-73,130,137-140,166-168] may help to generate new data and metrics concerning differences between predominantly outpatient versus inpatient chemotherapy delivery and admissions for chemotherapy and amelioration of serious adverse events (SAEs). For example, this approach could ask for (number of hospital days/year) to generate a new ePRO metric of quality and cost of cancer care. This approach could facilitate a quantitative study of variables such as lymphopenia, albumin, glucose control, sarcopenia, and weight loss in relation to clinic days, hospital days, documented infections, disease-free survival, and overall survival.

Quality metrics offer an important on-going means for oncology programs to adapt and adopt the best practices to facilitate better eating during cancer therapy. Prompt responding to PRO data may also contribute positively to the complex and bidirectional nature of reducing chemotherapy and radiation toxicity with concurrent improvements in eating. (Figure 1). PRO may also help cancer patients and caregivers to better sort out major versus minor contributors to eating behavior and well-being as well as staying "ontrack" during treatment and avoiding polypharmacy or worse: ineffective, and potentially harmful supplements and unproven alternative treatments [41,74,128-132,169].

To facilitate better short-term and long-term outcomes, the oncology team's efforts should strive to have reliable and predictable care and to reduce "battle fatigue". This involves flexible and adaptable scheduling, reducing futile care, and fewer interventions that miss the mark concerning cancer control (Figure 2) in addition to developing therapeutic alliances to continue sustainable efforts (Table 6). This team approach also may use radiation to reduce pain or definitively treat life-limiting metastases with SBRT to reduce both cancer burden and "scanxiety". A combination of therapeutic alliances to facilitate state-of-the-art cancer treatment with toxicity reduction, better eating behaviors, and improved quantity and quality of nutrient intake can help the patient and oncology team feel they have performed to their best to facilitate an improved cancer outcome.

\section{Summary and Conclusions}

This article reviews the complex and often bidirectional variables associated with chemotherapy and radiation toxicities and their effects on eating behaviors. A proactive and adaptive approach using feedback for toxicity and side-effect amelioration is advocated. In conclusion, developing better therapeutic alliances to reduce chemotherapy and radiation toxicities are important for oncology professionals, others in the medical center, and in the cancer patient's social and community networks.

\section{Patents}

PM Anderson glutamine and trehalose compositions US2015/0080331 pub date 19 March 2015.

Funding: This review received no external funding and was supported by the Cleveland Clinic Sarcoma Program.

Institutional Review Board Statement: Not applicable.

Informed Consent Statement: Not applicable.

Acknowledgments: The authors acknowledge the support and encouragement of many dietitians, oncology pharmacists, investigational pharmacists, nurses, and other oncology professionals 
and caregivers who have partnered to make lives better during chemotherapy and radiation at the University of Minnesota, Mayo Clinic, MD Anderson Cancer Center, and Cleveland Clinic. PMA is particularly grateful for facilitation of efforts by Peggy Bird, Rabi Hanna, Sammi Garzone, and Kelli Newman at Cleveland Clinic to do more virtual visits and on-line consults to help cancer patients and caregivers with cancer treatment and supportive care strategies including mitigation of chemotherapy and radiation toxicity and improving therapeutic alliances. The opportunity of PMA to participate as a guest editor in a Nutrients special issue on Diet and Nutrition during Chemotherapy and Radiation, a life-long interest, is much very much appreciated. Finally, P.M.A., S.M.T., S.S., K.S., and S.B. recognize the efforts of Kristen Powaski, our Pediatrics Institute outpatient nurse manager and Rabi Hanna to foster a culture of continuous improvement and family-centered care including this article.

Conflicts of Interest: The author is on the scientific review board of Enlivity, distributor of Healios.

\section{Abbreviations}

\begin{tabular}{|c|c|c|}
\hline Abbreviation & Spelling & Context and Comment \\
\hline SBRT & Sterotactic body radiotherapy & Very precise radiation given in $1-5$ treatment sessions \\
\hline MASCC & $\begin{array}{l}\text { Multinational Association for Supportive Care } \\
\text { in Cancer }\end{array}$ & $\begin{array}{l}\text { Organization which includes experts that provide guidelines for } \\
\text { improving side effects of cancer and cancer treatment }\end{array}$ \\
\hline ESMO & European Society of Clinical Oncology & $\begin{array}{l}\text { Organization of cancer professionals to share information and guidelines } \\
\text { to develop better ways to treat cancer in Europe and other regions. The } \\
\text { academic journal is ESMO Open }\end{array}$ \\
\hline ASCO & American Society of Clinical Oncology & $\begin{array}{c}\text { World's largest organization of cancer professionals to share information } \\
\text { and guidelines to develop better ways to treat cancer. Academic journal is } \\
\text { the Journal of Clinical Oncology }\end{array}$ \\
\hline $\mathrm{NCCN}$ & National Comprehensive Cancer Network & $\begin{array}{l}\text { An organization devoted to providing guidelines for treatment of specific } \\
\text { cancers and issues related to cancer treatment }\end{array}$ \\
\hline PG-SGA & $\begin{array}{l}\text { Patient Generated Subjective } \\
\text { Global Assessment }\end{array}$ & $\begin{array}{l}\text { A tool to help identify malnutrition and cachexia in cancer patients at risk } \\
\text { for sarcopenia }\end{array}$ \\
\hline OBD & Optimal biologic dose & $\begin{array}{c}\text { Dose of an agent that achieves best effect against a target with acceptable } \\
\text { toxicity (for example effect on immune activation) }\end{array}$ \\
\hline MTD & Maximally tolerated dose & $\begin{array}{l}\text { Dose of a drug (e.g., chemotherapy drug) for which an increase dose } \\
\text { would have unacceptable toxicity. Once the MTD is determined in a phase } \\
\text { I clinical trial, this becomes the recommended phase } 2 \text { dose of } \\
\text { an anti-cancer agent }\end{array}$ \\
\hline AUC & Area under the curve & $\begin{array}{l}\text { A pharmacokinetic/pharmacodynamic concept that reflects the graph of } \\
\text { drug concentration over time. Usually, an inverted U shape because of } \\
\text { absorption, distribution, and metabolism, and elimination of an agent }\end{array}$ \\
\hline VEGF & Vascular endothelial growth factor & $\begin{array}{l}\text { A protein involved in generation of new blood vessels to heal wounds or } \\
\text { injury or associated with tumors growing new blood vessels. Some } \\
\text { anti-cancer drugs block VEGF }\end{array}$ \\
\hline NG & Naso-gastric & $\begin{array}{l}\text { Usually refers to thin tube that extends from the nose to the stomach to } \\
\text { provide liquid nutrition, suspensions of drugs, or fluids } \\
\text { without swallowing }\end{array}$ \\
\hline G-tube & Gastrostomy tube & $\begin{array}{l}\text { A tube that goes directly from abdominal skin through the muscles and } \\
\text { lining of the abdomen into the stomach. Same use as NG but without the } \\
\text { discomfort of a tube in the nose or back of the throat }\end{array}$ \\
\hline SRS & Stereotactic radiosurgery & $\begin{array}{l}\text { Ultraprecise radiation that may require a "halo" device or anesthesia to } \\
\text { give the dose to tumor only in the brain or near the spinal cord }\end{array}$ \\
\hline $\mathrm{N} / \mathrm{V}$ & Nausea and/or vomiting & The most common side effect of cancer chemotherapy \\
\hline $5 \mathrm{HT}$ & 5-hydroxytryptamine (serotonin) & $\begin{array}{l}\text { The 5-HT3 receptor is triggered in the brain chemoreceptor trigger zone to } \\
\text { cause drug associated N/V. Inhibitors of 5-HT are very useful as } \\
\text { anti-emetics to reduce or prevent chemotherapy associated N/V }\end{array}$ \\
\hline $\mathrm{TPN}$ & Total parenteral nutrition & $\begin{array}{l}\text { An intravenous solution containing glucose, amino acids, vitamins, } \\
\text { and sometimes lipids that is used when patients cannot eat or drink } \\
\text { adequate amounts of nutrients }\end{array}$ \\
\hline
\end{tabular}




\begin{tabular}{|c|c|c|}
\hline Abbreviation & Spelling & Context and Comment \\
\hline TKI & Tyrosine kinase inhibitors & $\begin{array}{l}\text { A class of drugs that act to block cancer-associated tyrosine kinase } \\
\text { enzyme(s) in cancer cells that facilitate cancer growth }\end{array}$ \\
\hline WART & Whole abdominal radiotherapy & $\begin{array}{l}\text { A radiation technique to provide a moderately high dose of radiation to } \\
\text { the entire abdomen with relative sparing of liver and kidneys and treating } \\
\text { intestines and intestinal lining to tolerance dose. }\end{array}$ \\
\hline RT & Radiotherapy & Use of radiation as a treatment modality for cancer \\
\hline BMT & Bone marrow transplant & $\begin{array}{l}\text { High-dose chemotherapy followed by infusion of marrow or blood stem } \\
\text { cells to allow recovery of blood cell production }\end{array}$ \\
\hline G-CSF & Granulocyte colony stimulating factor & $\begin{array}{c}\text { A subcutaneous injection given after chemotherapy to increase } \\
\text { granulocyte (neutrophil) production by the bone marrow to make } \\
\text { chemotherapy safer }\end{array}$ \\
\hline KPS & Karnofsky performance scale & $\begin{array}{l}\text { A scale from } 0 \% \text { (dead) to } 100 \% \text { (full activity without limitation) to } \\
\text { indicate how active a cancer patient is and whether or not activity } \\
\text { (performance) is limited by symptoms of drugs, radiation, or cancer }\end{array}$ \\
\hline $\mathrm{PT} / \mathrm{OT}$ & Physical therapy and/or occupational therapy & $\begin{array}{c}\text { PT involves improving function, exercise, and strength training. OT } \\
\text { involves learning how to do activities of daily living better (e.g., climbing } \\
\text { stairs, opening a jar, buttoning a shirt) }\end{array}$ \\
\hline GNRI & Geriatric Nutrition Risk Index & $\begin{array}{l}\text { A composite compilation of risk factors to help with malnutritional } \\
\text { assessment in older people }\end{array}$ \\
\hline MNA & Mini-Nutritional Assessment & $\begin{array}{l}\text { A composite compilation of risk factors to help with } \\
\text { malnutritional assessment }\end{array}$ \\
\hline $\mathrm{PRO}$ & Patient reported outcome & A self-assessment form (if electronic it is an ePRO) \\
\hline BMI & Body mass index & $\begin{array}{l}\text { A calculation involving height and weight that can give a number to } \\
\text { indicate thin, normal or obese (e.g., } \mathrm{BMI}>30)\end{array}$ \\
\hline
\end{tabular}

\section{References}

1. Islami, F.; Ward, E.M.; Sung, H.; Cronin, K.A.; Tangka, F.K.L.; Sherman, R.L.; Zhao, J.; Anderson, R.N.; Henley, S.J.; Yabroff, K.R.; et al. Annual report to the nation on the status of cancer, Part 1: National cancer statistics. J. Natl. Cancer Inst. 2021, 113, 1648-1669. [CrossRef] [PubMed]

2. Siegel, R.L.; Miller, K.D.; Fuchs, H.E.; Jemal, A. Cancer statistics, 2021. CA Cancer J. Clin. 2021, 71, 7-33. [CrossRef] [PubMed]

3. Miller, K.D.; Nogueira, L.; Mariotto, A.B.; Rowland, J.H.; Yabroff, K.R.; Alfano, C.M.; Jemal, A.; Kramer, J.L.; Siegel, R.L. Cancer treatment and survivorship statistics, 2019. CA Cancer J. Clin. 2019, 69, 363-385. [CrossRef] [PubMed]

4. Ferlay, J.; Colombet, M.; Soerjomataram, I.; Parkin, D.M.; Pineros, M.; Znaor, A.; Bray, F. Cancer statistics for the year 2020: An overview. Int. J. Cancer 2021, 149, 778-789. [CrossRef]

5. Bradley, C.J.; Yabroff, K.R.; Zafar, S.Y.; Shih, Y.T. Time to add screening for financial hardship as a quality measure? CA Cancer J. Clin. 2021, 71, 100-106. [CrossRef]

6. Warren, J.L.; Yabroff, K.R.; Meekins, A.; Topor, M.; Lamont, E.B.; Brown, M.L. Evaluation of trends in the cost of initial cancer treatment. J. Natl. Cancer Inst. 2008, 100, 888-897. [CrossRef]

7. Yabroff, K.R.; Davis, W.W.; Lamont, E.B.; Fahey, A.; Topor, M.; Brown, M.L.; Warren, J.L. Patient time costs associated with cancer care. J. Natl. Cancer Inst. 2007, 99, 14-23. [CrossRef]

8. Pisu, M.; Henrikson, N.B.; Banegas, M.P.; Yabroff, K.R. Costs of cancer along the care continuum: What we can expect based on recent literature. Cancer 2018, 124, 4181-4191. [CrossRef]

9. Mariotto, A.B.; Yabroff, K.R.; Shao, Y.; Feuer, E.J.; Brown, M.L. Projections of the cost of cancer care in the United States: 2010-2020. J. Natl. Cancer Inst. 2011, 103, 117-128. [CrossRef]

10. Banegas, M.P.; Yabroff, K.R. Out of pocket, out of sight? An unmeasured component of the burden of cancer. J. Natl. Cancer Inst. 2013, 105, 252-253. [CrossRef]

11. Yabroff, K.R.; Bradley, C.J.; Mariotto, A.B.; Brown, M.L.; Feuer, E.J. Estimates and projections of value of life lost from cancer deaths in the United States. J. Natl. Cancer Inst. 2008, 100, 1755-1762. [CrossRef]

12. Yabroff, K.R.; Lund, J.; Kepka, D.; Mariotto, A. Economic burden of cancer in the United States: Estimates, projections, and future research. Cancer Epidemiol. Biomark. Prev. 2011, 20, 2006-2014. [CrossRef]

13. Thomas, T.; Hughes, T.; Mady, L.; Belcher, S.M. Financial toxicity: A review of the literature and nursing opportunities. Clin. J. Oncol. Nurs. 2019, 23, 5-13. [CrossRef]

14. Bowen, J.M.; Elad, S.; Hutchins, R.D.; Lalla, R.V.; Mucositis study group of the multinational association of supportive care in cancer/international society of Oral Oncology. Methodology for the MASCC/ISOO mucositis clinical practice guidelines update. Support. Care Cancer 2013, 21, 303-308. [CrossRef]

15. Elad, S. The MASCC/ISOO mucositis guidelines 2019: The second set of articles and future directions. Support. Care Cancer 2020, 28, 2445-2447. [CrossRef] 
16. Elad, S.; Bowen, J.; Zadik, Y.; Lalla, R.V.; Mucositis study group of the multinational association of supportive care in cancer/international society of Oral Oncology. Development of the MASCC/ISOO clinical practice guidelines for mucositis: Considerations underlying the process. Support. Care Cancer 2013, 21, 309-312. [CrossRef]

17. Elad, S.; Cheng, K.K.F.; Lalla, R.V.; Yarom, N.; Hong, C.; Logan, R.M.; Bowen, J.; Gibson, R.; Saunders, D.P.; Zadik, Y.; et al. MASCC/ISOO clinical practice guidelines for the management of mucositis secondary to cancer therapy. Cancer 2020, 126, 4423-4431. [CrossRef]

18. Lalla, R.V. The MASCC/ISOO mucositis guidelines update: Introduction to the first set of articles. Support. Care Cancer 2013, 21, 301-302. [CrossRef]

19. McKenzie, E.; Zaki, P.; Raman, S.; Olson, R.; McFarlane, T.; DeAngelis, C.; Chan, S.; Pidduck, W.; Razvi, Y.; Bushehri, A.; et al. Radiation-induced nausea and vomiting: A comparison between MASCC/ESMO, ASCO, and NCCN antiemetic guidelines. Support. Care Cancer 2019, 27, 783-791. [CrossRef]

20. Ranna, V.; Cheng, K.K.F.; Castillo, D.A.; Porcello, L.; Vaddi, A.; Lalla, R.V.; Bossi, P.; Elad, S.; Mucositis study group of the Multinational Association of Supportive Care in Cancer/International Society for Oral Oncology. Development of the MASCC/ISOO clinical practice guidelines for mucositis: An overview of the methods. Support. Care Cancer 2019, 27, 3933-3948. [CrossRef]

21. Razvi, Y.; Chan, S.; McFarlane, T.; McKenzie, E.; Zaki, P.; DeAngelis, C.; Pidduck, W.; Bushehri, A.; Chow, E.; Jerzak, K.J. ASCO, NCCN, MASCC/ESMO: A comparison of antiemetic guidelines for the treatment of chemotherapy-induced nausea and vomiting in adult patients. Support. Care Cancer 2019, 27, 87-95. [CrossRef]

22. Meazza, C.; Casanova, M.; Luksch, R.; Podda, M.; Favini, F.; Cefalo, G.; Massimino, M.; Ferrari, A. Prolonged 14-day continuous infusion of high-dose ifosfamide with an external portable pump: Feasibility and efficacy in refractory pediatric sarcoma. Pediatr. Blood Cancer 2010, 55, 617-620. [CrossRef]

23. Anderson, P. Continuously improving ifosfamide/mesna: A winning combination. Pediatr. Blood Cancer 2010, 55, 599-600. [CrossRef]

24. Peterson, D.E.; Ohrn, K.; Bowen, J.; Fliedner, M.; Lees, J.; Loprinzi, C.; Mori, T.; Osaguona, A.; Weikel, D.S.; Elad, S.; et al. Systematic review of oral cryotherapy for management of oral mucositis caused by cancer therapy. Support. Care Cancer 2013, 21, 327-332. [CrossRef]

25. Correa, M.E.P.; Cheng, K.K.F.; Chiang, K.; Kandwal, A.; Loprinzi, C.L.; Mori, T.; Potting, C.; Rouleau, T.; Toro, J.J.; Ranna, V.; et al. Systematic review of oral cryotherapy for the management of oral mucositis in cancer patients and clinical practice guidelines. Support. Care Cancer 2019, 28, 2457-2472. [CrossRef]

26. Park, S.H.; Lee, H.S. Meta-analysis of oral cryotherapy in preventing oral mucositis associated with cancer therapy. Int. J. Nurs. Pract. 2019, 25, e12759. [CrossRef]

27. Wang, L.; Gu, Z.; Zhai, R.; Zhao, S.; Luo, L.; Li, D.; Zhao, X.; Wei, H.; Pang, Z.; Wang, L.; et al. Efficacy of oral cryotherapy on oral mucositis prevention in patients with hematological malignancies undergoing hematopoietic stem cell transplantation: A meta-analysis of randomized controlled trials. PLoS ONE 2015, 10, e0128763. [CrossRef]

28. Todorova, V.K.; Harms, S.A.; Kaufmann, Y.; Luo, S.; Luo, K.Q.; Babb, K.; Klimberg, V.S. Effect of dietary glutamine on tumor glutathione levels and apoptosis-related proteins in DMBA-induced breast cancer of rats. Breast Cancer Res. Treat. 2004, 88, 247-256. [CrossRef]

29. Rouse, K.; Nwokedi, E.; Woodliff, J.E.; Epstein, J.; Klimberg, V.S. Glutamine enhances selectivity of chemotherapy through changes in glutathione metabolism. Ann. Surg. 1995, 221, 420-426. [CrossRef]

30. Rubio, I.; Suva, L.J.; Todorova, V.; Bhattacharyya, S.; Kaufmann, Y.; Maners, A.; Smith, M.; Klimberg, V.S. Oral glutamine reduces radiation morbidity in breast conservation surgery. JPEN J. Parenter. Enter. Nutr. 2013, 37, 623-630. [CrossRef]

31. Breglio, A.M.; Rusheen, A.E.; Shide, E.D.; Fernandez, K.A.; Spielbauer, K.K.; McLachlin, K.M.; Hall, M.D.; Amable, L.; Cunningham, L.L. Cisplatin is retained in the cochlea indefinitely following chemotherapy. Nat. Commun. 2017, 8, 1654. [CrossRef] [PubMed]

32. Scott, J.G.; Sedor, G.; Ellsworth, P.; Scarborough, J.A.; Ahmed, K.A.; Oliver, D.E.; Eschrich, S.A.; Kattan, M.W.; Torres-Roca, J.F. Pan-cancer prediction of radiotherapy benefit using genomic-adjusted radiation dose (GARD): A cohort-based pooled analysis. Lancet Oncol. 2021, 22, 1221-1229. [CrossRef]

33. Kaidar-Person, O.; Poortmans, P.; Salgado, R. Genomic-adjusted radiation dose to personalise radiotherapy. Lancet Oncol. 2021, 22, 1200-1201. [CrossRef]

34. Scott, J.G.; Harrison, L.B.; Torres-Roca, J.F. Genomic-adjusted radiation dose-Authors' reply. Lancet Oncol. 2017, 18, e129. [CrossRef]

35. De Sousa, I.M.; Silva, F.M.; de Carvalho, A.L.M.; da Rocha, I.M.G.; Fayh, A.P.T. Accuracy of isolated nutrition indicators in diagnosing malnutrition and their prognostic value to predict death in patients with gastric and colorectal cancer: A prospective study. JPEN J. Parenter. Enter. Nutr. 2021, 1-9. [CrossRef]

36. Deftereos, I.; Djordjevic, A.; Carter, V.M.; McNamara, J.; Yeung, J.M.; Kiss, N. Malnutrition screening tools in gastrointestinal cancer: A systematic review of concurrent validity. Surg. Oncol. 2021, 38, 101627. [CrossRef]

37. Gascon-Ruiz, M.; Casas-Deza, D.; Torres-Ramon, I.; Zapata-Garcia, M.; Alonso, N.; Sesma, A.; Lambea, J.; Alvarez-Alejandro, M.; Quilez, E.; Isla, D.; et al. Comparation of different malnutrition screening tools according to GLIM criteria in cancer outpatients. Eur. J. Clin. Nutr. 2021, 9, 1898. [CrossRef] 
38. Gebremedhin, T.K.; Cherie, A.; Tolera, B.D.; Atinafu, B.T.; Demelew, T.M. Prevalence and risk factors of malnutrition among adult cancer patients receiving chemotherapy treatment in cancer center, Ethiopia: Cross-sectional study. Heliyon 2021, 7, e07362. [CrossRef]

39. Hunter, M.; Kellett, J.; Toohey, K.; D'Cunha, N.M.; Isbel, S.; Naumovski, N. Toxicities caused by head and neck cancer treatments and their influence on the development of malnutrition: Review of the literature. Eur. J. Investig. Health Psychol. Educ. 2020, 10, 66. [CrossRef]

40. Kenny, E.; Samavat, H.; Touger-Decker, R.; Parrott, J.S.; Byham-Gray, L.; August, D.A. Adverse perioperative outcomes among patients undergoing gastrointestinal cancer surgery: Quantifying attributable risk from malnutrition. JPEN J. Parenter. Enteral. Nutr. 2021. [CrossRef]

41. Kose, E.; Wakabayashi, H.; Yasuno, N. Polypharmacy and malnutrition management of elderly perioperative patients with cancer: A systematic review. Nutrients 2021, 13, 1961. [CrossRef]

42. Levonyak, N.S.; Hodges, M.P.; Haaf, N.; Brown, T.J.; Hardy, S.; Mhoon, V.; Kainthla, R.; Beg, M.S.; Kazmi, S.M. Importance of addressing malnutrition in cancer and implementation of a quality improvement project in a gastrointestinal cancer clinic. Nutr. Clin. Pract. 2021, 107, 2411-2502. [CrossRef]

43. Li, Q.; Zhang, X.; Tang, M.; Song, M.; Zhang, Q.; Zhang, K.; Ruan, G.; Zhang, X.; Ge, Y.; Yang, M.; et al. Different muscle mass indices of the global leadership initiative on malnutrition in diagnosing malnutrition and predicting survival of patients with gastric cancer. Nutrition 2021, 89, 111286. [CrossRef]

44. Muscaritoli, M.; Corsaro, E.; Molfino, A. Awareness of cancer-related malnutrition and its management: Analysis of the results from a survey conducted among medical oncologists. Front. Oncol. 2021, 11, 682999. [CrossRef]

45. Nakyeyune, R.; Ruan, X.; Shen, Y.; Shao, Y.; Niu, C.; Zang, Z.; Liu, F. Diagnostic performance of SGA, PG-SGA and MUST for malnutrition assessment in adult cancer patients: A systematic literature review and hierarchical bayesian meta-analysis. Nutr. Cancer 2021, 1-13. [CrossRef]

46. Pingili, S.; Ahmed, J.; Sujir, N.; Shenoy, N.; Ongole, R. Evaluation of malnutrition and quality of life in patients treated for oral and oropharyngeal cancer. Sci. World J. 2021, 2021, 9936715. [CrossRef]

47. Sanchez-Torralvo, F.J.; Ruiz-Garcia, I.; Contreras-Bolivar, V.; Gonzalez-Almendros, I.; Ruiz-Vico, M.; Abuin-Fernandez, J.; Barrios, M.; Alba, E.; Olveira, G. CT-determined sarcopenia in GLIM-defined malnutrition and prediction of 6-month mortality in cancer inpatients. Nutrients 2021, 13, 2647. [CrossRef]

48. Wang, P.; Chen, X.; Liu, Q.; Liu, X.; Li, Y. Good performance of the global leadership initiative on malnutrition criteria for diagnosing and classifying malnutrition in people with esophageal cancer undergoing esophagectomy. Nutrition 2021, 91-92, 111420. [CrossRef]

49. Yan, X.; Zhang, S.; Jia, J.; Yang, J.; Song, Y.; Duan, H. Exploring the malnutrition status and impact of total parenteral nutrition on the outcome of patients with advanced stage ovarian cancer. BMC Cancer 2021, 21, 799. [CrossRef]

50. Yin, L.; Fan, Y.; Lin, X.; Zhang, L.; Li, N.; Liu, J.; Guo, J.; Zhang, M.; He, X.; Liu, L.; et al. Fat mass assessment using the triceps skinfold thickness enhances the prognostic value of the global leadership initiative on malnutrition criteria in patients with lung cancer. Br. J. Nutr. 2021, 1-11. [CrossRef]

51. Zhang, K.P.; Tang, M.; Fu, Z.M.; Zhang, Q.; Zhang, X.; Guo, Z.Q.; Xu, H.X.; Song, C.H.; Braga, M.; Cederholm, T.; et al. Global leadership initiative on malnutrition criteria as a nutrition assessment tool for patients with cancer. Nutrition 2021, 91-92, 111379. [CrossRef]

52. Anderson, P.M.; Hanna, R. Defining moments: Making time for virtual visits and catalyzing better cancer care. Health Commun. 2020, 35, 787-791. [CrossRef]

53. O'Hanlon, C.E.; Lindvall, C.; Giannitrapani, K.F.; Garrido, M.; Ritchie, C.; Asch, S.; Gamboa, R.C.; Canning, M.; Lorenz, K.A.; Walling, A.M.; et al. Expert stakeholder prioritization of process quality measures to achieve patient-and family-centered palliative and end-of-life cancer care. J. Palliat. Med. 2021, 24, 1321-1333. [CrossRef] [PubMed]

54. DeRosa, A.P.; Baltich Nelson, B.; Delgado, D.; Mages, K.C.; Martin, L.; Stribling, J.C. Involvement of information professionals in patient- and family-centered care initiatives: A scoping review. J. Med. Libr. Assoc. 2019, 107, 314-322. [CrossRef]

55. Crespo, C.; Santos, S.; Tavares, A.; Salvador, A. "Care that matters": Family-centered care, caregiving burden, and adaptation in parents of children with cancer. Fam. Syst. Health 2016, 34, 31-40. [CrossRef]

56. Michael, N.; O'Callaghan, C.; Baird, A.; Hiscock, N.; Clayton, J. Cancer caregivers advocate a patient-and family-centered approach to advance care planning. J. Pain Symptom Manag. 2014, 47, 1064-1077. [CrossRef]

57. Oshima, S.M.; Tait, S.D.; Thomas, S.M.; Fayanju, O.M.; Ingraham, K.; Barrett, N.J.; Hwang, E.S. Association of smartphone ownership and internet use with markers of health literacy and access: Cross-sectional survey study of perspectives from project PLACE (Population Level Approaches to Cancer Elimination). J. Med. Internet Res. 2021, 23, e24947. [CrossRef]

58. Keaver, L.; Yiannakou, I.; Folta, S.C.; Zhang, F.F. Perceptions of oncology providers and cancer survivors on the role of nutrition in cancer care and their views on the "NutriCare" program. Nutrients 2020, 12, 1277. [CrossRef]

59. Barreira, J.V. The role of nutrition in cancer patients. Nutr. Cancer 2020, 1-2. [CrossRef]

60. Barrett, M.; Ui Dhuibhir, P.; Njoroge, C.; Wickham, S.; Buchanan, P.; Aktas, A.; Walsh, D. Diet and nutrition information on nine national cancer organisation websites: A critical review. Eur. J. Cancer Care 2020, 29, e13280. [CrossRef] [PubMed]

61. Haskins, C.P.; Champ, C.E.; Miller, R.; Vyfhuis, M.A.L. Nutrition in cancer: Evidence and equality. Adv. Radiat. Oncol. 2020, 5, 817-823. [CrossRef] [PubMed] 
62. Richards, J.; Arensberg, M.B.; Thomas, S.; Kerr, K.W.; Hegazi, R.; Bastasch, M. Impact of early incorporation of nutrition interventions as a component of cancer therapy in adults: A review. Nutrients 2020, 12, 3403. [CrossRef] [PubMed]

63. Sullivan, E.S.; Rice, N.; Kingston, E.; Kelly, A.; Reynolds, J.V.; Feighan, J.; Power, D.G.; Ryan, A.M. A national survey of oncology survivors examining nutrition attitudes, problems and behaviours, and access to dietetic care throughout the cancer journey. Clin. Nutr. ESPEN 2021, 41, 331-339. [CrossRef] [PubMed]

64. Thorne, J.L.; Moore, J.B.; Corfe, B.M. Nutrition and cancer: Evidence gaps and opportunities for improving knowledge. Proc. Nutr. Soc. 2020, 79, 367-372. [CrossRef]

65. Trehan, A.; Viani, K.; da Cruz, L.B.; Sagastizado, S.Z.; Ladas, E.J. The importance of enteral nutrition to prevent or treat undernutrition in children undergoing treatment for cancer. Pediatr. Blood Cancer 2020, 67 (Suppl. 3), e28378. [CrossRef]

66. Koppold-Liebscher, D.; Kessler, C.S.; Steckhan, N.; Bahr, V.; Kempter, C.; Wischnewsky, M.; Hubner, M.; Kunz, B.; Paul, M.; Zorn, S.; et al. Short-term fasting accompanying chemotherapy as a supportive therapy in gynecological cancer: Protocol for a multicenter randomized controlled clinical trial. Trials 2020, 21, 854. [CrossRef]

67. Sadeghian, M.; Rahmani, S.; Khalesi, S.; Hejazi, E. A review of fasting effects on the response of cancer to chemotherapy. Clin. Nutr. 2021, 40, 1669-1681. [CrossRef]

68. Tang, X.; Li, G.; Shi, L.; Su, F.; Qian, M.; Liu, Z.; Meng, Y.; Sun, S.; Li, J.; Liu, B. Combined intermittent fasting and ERK inhibition enhance the anti-tumor effects of chemotherapy via the GSK3beta-SIRT7 axis. Nat. Commun. 2021, 12, 5058. [CrossRef]

69. Cong, M.; Song, C.; Xu, H.; Song, C.; Wang, C.; Fu, Z.; Ba, Y.; Wu, J.; Xie, C.; Chen, G.; et al. The patient-generated subjective global assessment is a promising screening tool for cancer cachexia. BMJ Support. Palliat. Care 2020. [CrossRef]

70. Jager-Wittenaar, H.; de Bats, H.F.; Welink-Lamberts, B.J.; Gort-van Dijk, D.; van der Laan, B.; Ottery, F.D.; Roodenburg, J.L.N. Self-completion of the patient-generated subjective global assessment short form is feasible and is associated with increased awareness on malnutrition risk in patients with head and neck cancer. Nutr. Clin. Pract. 2020, 35, 353-362. [CrossRef]

71. De Groot, L.M.; Lee, G.; Ackerie, A.; van der Meij, B.S. Malnutrition screening and assessment in the cancer care ambulatory setting: Mortality predictability and validity of the patient-generated subjective global assessment short form (PG-SGA SF) and the GLIM criteria. Nutrients 2020, 12, 2287. [CrossRef]

72. De Oliveira Pereira, F.; Pereira Mota, A.; Azevedo Aredes, M.; Villaca Chaves, G.; Ramos Cardoso, I.C. Association between scored patient-generated subjective global assessment and skeletal muscle determined by computed tomography in patients with cervical cancer. Nutr. Cancer 2020, 72, 595-601. [CrossRef]

73. Cavalcante Martins, F.F.; de Pinho, N.B.; de Carvalho Padilha, P.; Martucci, R.B.; Rodrigues, V.D.; Sales, R.C.; Ferreira Peres, W.A. Patient-generated subjective global assessment predicts cachexia and death in patients with head, neck and abdominal cancer: A retrospective longitudinal study. Clin. Nutr. ESPEN 2019, 31, 17-22. [CrossRef]

74. Pana, A.; Sourtzi, P.; Kalokairinou, A.; Velonaki, V.S. Sarcopenia and polypharmacy among older adults: A scoping review of the literature. Arch. Gerontol. Geriatr. 2021, 98, 104520. [CrossRef]

75. Shachar, S.S.; Williams, G.R.; Muss, H.B.; Nishijima, T.F. Prognostic value of sarcopenia in adults with solid tumours: A meta-analysis and systematic review. Eur. J. Cancer 2016, 57, 58-67. [CrossRef]

76. Sugiyama, K. Sarcopenia and Nutrition Support in the Treatment of Gastric Cancer. Gan Kagaku Ryoho 2020, 47, $1542-1546$.

77. Williams, G.R.; Deal, A.M.; Muss, H.B.; Weinberg, M.S.; Sanoff, H.K.; Nyrop, K.A.; Pergolotti, M.; Shachar, S.S. Skeletal muscle measures and physical function in older adults with cancer: Sarcopenia or myopenia? Oncotarget 2017, 8, 33658-33665. [CrossRef]

78. Klassen, P.; Baracos, V.; Gramlich, L.; Nelson, G.; Mazurak, V.; Martin, L. Computed-tomography body composition analysis complements pre-operative nutrition screening in colorectal cancer patients on an enhanced recovery after surgery pathway. Nutrients 2020, 12, 3745. [CrossRef]

79. Neoh, M.K.; Abu Zaid, Z.; Mat Daud, Z.A.; Md Yusop, N.B.; Ibrahim, Z.; Abdul Rahman, Z.; Jamhuri, N. Changes in nutrition impact symptoms, nutritional and functional status during head and neck cancer treatment. Nutrients 2020, 12, 1225. [CrossRef]

80. Opanga, Y.; Kaduka, L.; Bukania, Z.; Mutisya, R.; Korir, A.; Thuita, V.; Mwangi, M.; Muniu, E.; Mbakaya, C. Nutritional status of cancer outpatients using scored patient generated subjective global assessment in two cancer treatment centers, Nairobi, Kenya. BMC Nutr. 2017, 3, 63. [CrossRef]

81. Guo, X.; Peters, M.D.J.; Lu, Z. Management of skin toxicity caused by epidermal growth factor receptor inhibitors: An evidencebased implementation project. JBI Database Syst. Rev. Implement Rep. 2017, 15, 2815-2829. [CrossRef]

82. Bechtel, A.S.; Indelicato, D.J.; Sandler, E. Enteral nutrition in pediatric high-risk head and neck cancer patients receiving proton therapy: Identifying risk factors and quality of life concerns to optimize care. J. Pediatr. Hematol. Oncol. 2019, 41, e247-e253. [CrossRef]

83. Wang, Z.; Peng, Y.; Cai, X.; Cao, Y.; Yang, G.; Huang, P. Impact of total parenteral nutrition standardization led by pharmacist on quality in postoperative patients with colorectal cancer. Eur. J. Clin. Nutr. 2019, 73, 243-249. [CrossRef]

84. Suehiro, M.; Kojima, Y.; Takahashi, M.; Ito, Y.; Keira, T.; Ikegawa, K.; Minatogawa, H.; Tsugawa, K.; Tanaka, T. Antiemetic efficacy of adding olanzapine $5 \mathrm{mg}$ to aprepitant, palonosetron and dexamethasone-sparing after day two for cancer patients receiving anthracycline and cyclophosphamide. Cancer Manag. Res. 2021, 13, 1617-1624. [CrossRef]

85. Cabanillas Stanchi, K.M.; Willier, S.; Vek, J.; Schlegel, P.; Queudeville, M.; Rieflin, N.; Klaus, V.; Gansel, M.; Rupprecht, J.V.; Flaadt, T.; et al. Antiemetic prophylaxis with fosaprepitant and 5-HT3-receptor antagonists in pediatric patients undergoing autologous hematopoietic stem cell transplantation. Drug Des. Devel. Ther. 2020, 14, 3915-3927. [CrossRef]

86. Hsu, Y.C.; Chen, C.Y.; Tam, K.W.; Hsu, C.Y. Effectiveness of palonosetron versus granisetron in preventing chemotherapy-induced nausea and vomiting: A systematic review and meta-analysis. Eur. J. Clin. Pharmacol. 2021, 77, 1597-1609. [CrossRef] 
87. Van der Vorst, M.; Toffoli, E.C.; Beusink, M.; van Linde, M.E.; van Voorthuizen, T.; Brouwer, S.; van Zweeden, A.A.; Vrijaldenhoven, S.; Berends, J.C.; Berkhof, J.; et al. Metoclopramide, dexamethasone, or palonosetron for prevention of delayed chemotherapyinduced nausea and vomiting after moderately emetogenic chemotherapy (MEDEA): A randomized, phase III, noninferiority trial. Oncologist 2021, 26, e173-e181. [CrossRef]

88. Willier, S.; Cabanillas Stanchi, K.M.; von Have, M.; Binder, V.; Blaeschke, F.; Feucht, J.; Feuchtinger, T.; Doring, M. Efficacy, safety and feasibility of fosaprepitant for the prevention of chemotherapy-induced nausea and vomiting in pediatric patients receiving moderately and highly emetogenic chemotherapy-Results of a non-interventional observation study. BMC Cancer 2019, 19, 1118. [CrossRef]

89. Anderson, P.M.; Lalla, R.V. Glutamine for amelioration of radiation and chemotherapy associated mucositis during cancer therapy. Nutrients 2020, 12, 1675. [CrossRef]

90. Anderson, P.M.; Ramsay, N.K.; Shu, X.O.; Rydholm, N.; Rogosheske, J.; Nicklow, R.; Weisdorf, D.J.; Skubitz, K.M. Effect of low-dose oral glutamine on painful stomatitis during bone marrow transplantation. Bone Marrow Transpl. 1998, 22, 339-344. [CrossRef] [PubMed]

91. Anderson, P.M.; Schroeder, G.; Skubitz, K.M. Oral glutamine reduces the duration and severity of stomatitis after cytotoxic cancer chemotherapy. Cancer 1998, 83, 1433-1439. [CrossRef]

92. Skubitz, K.M.; Anderson, P.M. Oral glutamine to prevent chemotherapy induced stomatitis: A pilot study. J. Lab. Clin. Med. 1996, 127, 223-228. [CrossRef]

93. Al-Dasooqi, N.; Sonis, S.T.; Bowen, J.M.; Bateman, E.; Blijlevens, N.; Gibson, R.J.; Logan, R.M.; Nair, R.G.; Stringer, A.M.; Yazbeck, R.; et al. Emerging evidence on the pathobiology of mucositis. Support. Care Cancer 2013, 21, 3233-3241. [CrossRef] [PubMed]

94. Chen, S.C.; Lai, Y.H.; Huang, B.S.; Lin, C.Y.; Fan, K.H.; Chang, J.T. Changes and predictors of radiation-induced oral mucositis in patients with oral cavity cancer during active treatment. Eur. J. Oncol. Nurs. 2015, 19, 214-219. [CrossRef]

95. Lalla, R.V.; Saunders, D.P.; Peterson, D.E. Chemotherapy or radiation-induced oral mucositis. Dent. Clin. N. Am. 2014, 58, 341-349. [CrossRef]

96. Tobin, J.L.; Thomas, S.M.; Freyer, D.R.; Hamilton, A.S.; Milam, J.E. Estimating cancer treatment intensity from SEER cancer registry data: Methods and implications for population-based registry studies of pediatric cancers. Cancer Causes Control 2020, 31, 881-890. [CrossRef]

97. Beaven, A.W.; Shea, T.C. The effect of palifermin on chemotherapyand radiation therapy-induced mucositis: A review of the current literature. Support. Cancer Ther. 2007, 4, 188-197. [CrossRef]

98. Sonis, S.T. Efficacy of palifermin (keratinocyte growth factor-1) in the amelioration of oral mucositis. Core Evid. 2010, 4, 199-205. [CrossRef]

99. Reddy, G.K.; Jain, V.K. Palifermin is efficacious in reducing oral mucositis induced by intensive cancer therapy. Support. Cancer Ther. 2005, 2, 84-85. [CrossRef]

100. Le, Q.T.; Kim, H.E.; Schneider, C.J.; Murakozy, G.; Skladowski, K.; Reinisch, S.; Chen, Y.; Hickey, M.; Mo, M.; Chen, M.G.; et al. Palifermin reduces severe mucositis in definitive chemoradiotherapy of locally advanced head and neck cancer: A randomized, placebo-controlled study. J. Clin. Oncol. 2011, 29, 2808-2814. [CrossRef]

101. Vadhan-Raj, S.; Trent, J.; Patel, S.; Zhou, X.; Johnson, M.M.; Araujo, D.; Ludwig, J.A.; O’Roark, S.; Gillenwater, A.M.; Bueso-Ramos, C.; et al. Single-dose palifermin prevents severe oral mucositis during multicycle chemotherapy in patients with cancer: A randomized trial. Ann. Intern. Med. 2010, 153, 358-367. [CrossRef]

102. Huang, E.Y.; Leung, S.W.; Wang, C.J.; Chen, H.C.; Sun, L.M.; Fang, F.M.; Yeh, S.A.; Hsu, H.C.; Hsiung, C.Y. Oral glutamine to alleviate radiation-induced oral mucositis: A pilot randomized trial. Int. J. Radiat. Oncol. Biol. Phys. 2000, 46, 535-539. [CrossRef]

103. Klimberg, V.S.; Salloum, R.M.; Kasper, M.; Plumley, D.A.; Dolson, D.J.; Hautamaki, R.D.; Mendenhall, W.R.; Bova, F.C.; Bland, K.I.; Copeland, E.M.; et al. Oral glutamine accelerates healing of the small intestine and improves outcome after whole abdominal radiation. Arch. Surg. 1990, 125, 1040-1045. [CrossRef]

104. Klimberg, V.S.; Souba, W.W.; Dolson, D.J.; Salloum, R.M.; Hautamaki, R.D.; Plumley, D.A.; Mendenhall, W.M.; Bova, F.J.; Khan, S.R.; Hackett, R.L.; et al. Prophylactic glutamine protects the intestinal mucosa from radiation injury. Cancer 1990, 66, 62-68. [CrossRef]

105. Souba, W.W.; Klimberg, V.S.; Hautamaki, R.D.; Mendenhall, W.H.; Bova, F.C.; Howard, R.J.; Bland, K.I.; Copeland, E.M. Oral glutamine reduces bacterial translocation following abdominal radiation. J. Surg. Res. 1990, 48, 1-5. [CrossRef]

106. Aquino, V.M.; Harvey, A.R.; Garvin, J.H.; Godder, K.T.; Nieder, M.L.; Adams, R.H.; Jackson, G.B.; Sandler, E.S. A double-blind randomized placebo-controlled study of oral glutamine in the prevention of mucositis in children undergoing hematopoietic stem cell transplantation: A pediatric blood and marrow transplant consortium study. Bone Marrow Transpl. 2005, 36, 611-616. [CrossRef]

107. Schloerb, P.R.; Skikne, B.S. Oral and parenteral glutamine in bone marrow transplantation: A randomized, double-blind study. JPEN J. Parenter. Enter. Nutr. 1999, 23, 117-122. [CrossRef]

108. Wingard, J.R.; Niehaus, C.S.; Peterson, D.E.; Jones, R.J.; Piantadosi, S.; Levin, L.S.; Saral, R.; Santos, G.W. Oral mucositis after bone marrow transplantation. A marker of treatment toxicity and predictor of hepatic veno-occlusive disease. Oral Surg. Oral Med. Oral Pathol. 1991, 72, 419-424. [CrossRef] 
109. Ray-Coquard, I.; Cropet, C.; Van Glabbeke, M.; Sebban, C.; Le Cesne, A.; Judson, I.; Tredan, O.; Verweij, J.; Biron, P.; Labidi, I.; et al. Lymphopenia as a prognostic factor for overall survival in advanced carcinomas, sarcomas, and lymphomas. Cancer Res. 2009, 69, 5383-5391. [CrossRef]

110. De Angulo, G.; Yuen, C.; Palla, S.L.; Anderson, P.M.; Zweidler-McKay, P.A. Absolute lymphocyte count is a novel prognostic indicator in ALL and AML: Implications for risk stratification and future studies. Cancer 2008, 112, 407-415. [CrossRef]

111. Rubnitz, J.E.; Campbell, P.; Zhou, Y.; Sandlund, J.T.; Jeha, S.; Ribeiro, R.C.; Inaba, H.; Bhojwani, D.; Relling, M.V.; Howard, S.C.; et al. Prognostic impact of absolute lymphocyte counts at the end of remission induction in childhood acute lymphoblastic leukemia. Cancer 2013, 119, 2061-2066. [CrossRef]

112. Anderson, P.M. Immune therapy for sarcomas. Adv. Exp. Med. Biol. 2017, 995, 127-140. [CrossRef]

113. Shachar, S.S.; Deal, A.M.; Weinberg, M.; Nyrop, K.A.; Williams, G.R.; Nishijima, T.F.; Benbow, J.M.; Muss, H.B. Skeletal muscle measures as predictors of toxicity, hospitalization, and survival in patients with metastatic breast cancer receiving taxane-based chemotherapy. Clin. Cancer Res. 2017, 23, 658-665. [CrossRef]

114. Anderson, P.; Kaye, L. The therapeutic alliance: Adapting to the unthinkable with better information. Health Commun. 2009, 24, 775-778. [CrossRef]

115. Anderson, P.; Salazar-Abshire, M. Improving outcomes in difficult bone cancers using multimodality therapy, including radiation: Physician and nursing perspectives. Curr. Oncol. Rep. 2006, 8, 415-422. [CrossRef]

116. Aleixo, G.F.P.; Williams, G.R.; Nyrop, K.A.; Muss, H.B.; Shachar, S.S. Muscle composition and outcomes in patients with breast cancer: Meta-analysis and systematic review. Breast Cancer Res. Treat. 2019, 177, 569-579. [CrossRef]

117. Prado, C.M.; Purcell, S.A.; Laviano, A. Nutrition interventions to treat low muscle mass in cancer. J. Cachexia Sarcopenia Muscle 2020, 11, 366-380. [CrossRef]

118. Williams, G.R.; Deal, A.M.; Muss, H.B.; Weinberg, M.S.; Sanoff, H.K.; Guerard, E.J.; Nyrop, K.A.; Pergolotti, M.; Shachar, S.S. Frailty and skeletal muscle in older adults with cancer. J. Geriatr. Oncol. 2018, 9, 68-73. [CrossRef]

119. Lacey, J.M.; Wilmore, D.W. Is glutamine a conditionally essential amino acid? Nutr. Rev. 1990, 48, 297-309. [CrossRef]

120. Smith, R.J.; Wilmore, D.W. Glutamine nutrition and requirements. JPEN J. Parenter. Enter. Nutr. 1990, 14, 94S-99S. [CrossRef]

121. Souba, W.W.; Smith, R.J.; Wilmore, D.W. Glutamine metabolism by the intestinal tract. JPEN J. Parenter. Enter. Nutr. 1985, 9 , 608-617. [CrossRef] [PubMed]

122. Wilmore, D.W.; Shabert, J.K. Role of glutamine in immunologic responses. Nutrition 1998, 14, 618-626. [CrossRef]

123. Kaufmann, Y.; Spring, P.; Klimberg, V.S. Oral glutamine prevents DMBA-induced mammary carcinogenesis via upregulation of glutathione production. Nutrition 2008, 24, 462-469. [CrossRef] [PubMed]

124. Lim, V.; Korourian, S.; Todorova, V.K.; Kaufmann, Y.; Klimberg, V.S. Glutamine prevents DMBA-induced squamous cell cancer. Oral Oncol. 2009, 45, 148-155. [CrossRef]

125. Klimberg, S. Prevention of radiogenic side effects using glutamine-enriched elemental diets. Recent Results Cancer Res. 1991, 121, 283-285. [CrossRef]

126. Klimberg, V.S.; Nwokedi, E.; Hutchins, L.F.; Pappas, A.A.; Lang, N.P.; Broadwater, J.R.; Read, R.C.; Westbrook, K.C. Glutamine facilitates chemotherapy while reducing toxicity. JPEN J. Parenter. Enter. Nutr. 1992, 16, 83S-87S. [CrossRef]

127. Todorova, V.; Vanderpool, D.; Blossom, S.; Nwokedi, E.; Hennings, L.; Mrak, R.; Klimberg, V.S. Oral glutamine protects against cyclophosphamide-induced cardiotoxicity in experimental rats through increase of cardiac glutathione. Nutrition 2009, 25, 812-817. [CrossRef]

128. Barlow, A.; Prusak, E.S.; Barlow, B.; Nightingale, G. Interventions to reduce polypharmacy and optimize medication use in older adults with cancer. J. Geriatr. Oncol. 2021, 12, 863-871. [CrossRef]

129. Chen, L.J.; Trares, K.; Laetsch, D.C.; Nguyen, T.N.M.; Brenner, H.; Schottker, B. Systematic review and meta-analysis on the associations of polypharmacy and potentially inappropriate medication with adverse outcomes in older cancer patients. J. Gerontol. A Biol. Sci. Med. Sci. 2021, 76, 1044-1052. [CrossRef]

130. Flannery, M.A.; Mohile, S.; Culakova, E.; Norton, S.; Kamen, C.; Dionne-Odom, J.N.; DiGiovanni, G.; Griggs, L.; Bradley, T.; Hopkins, J.O.; et al. Completion of patient-reported outcome questionnaires among older adults with advanced cancer. J. Pain Symptom Manag. 2021. [CrossRef]

131. Guven, D.C.; Kavgaci, G.; Aktepe, O.H.; Yildirim, H.C.; Sahin, T.K.; Aksoy, S.; Erman, M.; Kilickap, S.; Yalcin, S. The burden of polypharmacy and drug-drug interactions in older cancer patients treated with immunotherapy. J. Oncol. Pharm. Pract. 2021. [CrossRef]

132. Nightingale, G.; Mohamed, M.R.; Holmes, H.M.; Sharma, M.; Ramsdale, E.; Lu-Yao, G.; Chapman, A. Research priorities to address polypharmacy in older adults with cancer. J. Geriatr. Oncol. 2021, 12, 964-970. [CrossRef]

133. Abd-El-Gawad, W.M.; Abou-Hashem, R.M.; El Maraghy, M.O.; Amin, G.E. The validity of geriatric nutrition risk index: Simple tool for prediction of nutritional-related complication of hospitalized elderly patients. Comparison with mini nutritional assessment. Clin. Nutr. 2014, 33, 1108-1116. [CrossRef]

134. Hung, C.Y.; Hsueh, S.W.; Lu, C.H.; Chang, P.H.; Chen, P.T.; Yeh, K.Y.; Wang, H.M.; Tsang, N.M.; Huang, P.W.; Hung, Y.S.; et al. A prospective nutritional assessment using mini nutritional assessment-short form among patients with head and neck cancer receiving concurrent chemoradiotherapy. Support. Care Cancer 2021, 29, 1509-1518. [CrossRef] 
135. Zhang, X.; Sun, M.; McKoy, J.M.; Bhulani, N.N.A.; Valero, V.; Barcenas, C.H.; Popat, U.R.; Sri, M.K.; Shah, J.B.; Dinney, C.P.; et al. Malnutrition in older patients with cancer: Appraisal of the mini nutritional assessment, weight loss, and body mass index. J. Geriatr. Oncol. 2018, 9, 81-83. [CrossRef]

136. Stover, A.M.; Kurtzman, R.; Walker Bissram, J.; Jansen, J.; Carr, P.; Atkinson, T.; Ellis, C.T.; Freeman, A.T.; Turner, K.; Basch, E.M. Stakeholder perceptions of key aspects of high-quality cancer care to assess with patient reported outcome measures: A systematic review. Cancers 2021, 13, 3628. [CrossRef]

137. Basch, E.; Becker, C.; Rogak, L.J.; Schrag, D.; Reeve, B.B.; Spears, P.; Smith, M.L.; Gounder, M.M.; Mahoney, M.R.; Schwartz, G.K.; et al. Composite grading algorithm for the national cancer institute's patient-reported outcomes version of the common terminology criteria for adverse events (PRO-CTCAE). Clin. Trials 2021, 18, 104-114. [CrossRef]

138. Denis, F.; Krakowski, I. How should oncologists choose an electronic patient-reported outcome system for remote monitoring of patients with cancer? J. Med. Internet Res. 2021, 23, e30549. [CrossRef]

139. Meryk, A.; Kropshofer, G.; Hetzer, B.; Riedl, D.; Lehmann, J.; Rumpold, G.; Haid, A.; Holzner, B.; Crazzolara, R. Implementation of daily patient-reported outcome measurements to support children with cancer. Pediatr. Blood Cancer 2021, 68, e29279. [CrossRef]

140. Peltola, M.K.; Poikonen-Saksela, P.; Mattson, J.; Parkkari, T. A novel digital patient-reported outcome platform (Noona) for clinical use in patients with cancer: Pilot study assessing suitability. JMIR Form. Res. 2021, 5, e16156. [CrossRef]

141. Li, D.; Sun, C.L.; Kim, H.; Soto-Perez-de-Celis, E.; Chung, V.; Koczywas, M.; Fakih, M.; Chao, J.; Cabrera Chien, L.; Charles, K.; et al. Geriatric assessment-driven intervention (GAIN) on chemotherapy-related toxic effects in older adults with cancer: A randomized clinical trial. JAMA Oncol. 2021, 7, e214158. [CrossRef]

142. Ando, Y.; Hayashi, T.; Shiouchi, H.; Tanaka, C.; Ito, K.; Nishibe, S.; Miyata, N.; Horiba, R.; Yanagi, H.; Fujii, T.; et al. Effect of obesity on hematotoxicity induced by carboplatin and paclitaxel combination therapy in patients with gynecological cancer. Biol. Pharm. Bull. 2020, 43, 669-674. [CrossRef]

143. Baracos, V.E.; Arribas, L. Sarcopenic obesity: Hidden muscle wasting and its impact for survival and complications of cancer therapy. Ann. Oncol. 2018, 29, ii1-ii9. [CrossRef]

144. Barone, I.; Caruso, A.; Gelsomino, L.; Giordano, C.; Bonofiglio, D.; Catalano, S.; Ando, S. Obesity and endocrine therapy resistance in breast cancer: Mechanistic insights and perspectives. Obes. Rev. 2021, e13358. [CrossRef]

145. Dieli-Conwright, C.M.; Courneya, K.S.; Demark-Wahnefried, W.; Sami, N.; Lee, K.; Buchanan, T.A.; Spicer, D.V.; Tripathy, D.; Bernstein, L.; Mortimer, J.E. Effects of aerobic and resistance exercise on metabolic syndrome, sarcopenic obesity, and circulating biomarkers in overweight or obese survivors of breast cancer: A randomized controlled trial. J. Clin. Oncol. 2018, 36, 875-883. [CrossRef]

146. Incio, J.; Ligibel, J.A.; McManus, D.T.; Suboj, P.; Jung, K.; Kawaguchi, K.; Pinter, M.; Babykutty, S.; Chin, S.M.; Vardam, T.D.; et al. Obesity promotes resistance to anti-VEGF therapy in breast cancer by up-regulating IL-6 and potentially FGF-2. Sci. Transl. Med. 2018, 10, eaag0945. [CrossRef]

147. Koneru, H.; Cyr, R.; Feng, L.R.; Bae, E.; Danner, M.T.; Ayoob, M.; Yung, T.M.; Lei, S.; Collins, B.T.; Saligan, L.; et al. The impact of obesity on patient reported outcomes following stereotactic body radiation therapy for prostate cancer. Cureus 2016, 8, e669. [CrossRef]

148. Lee, K.; Kruper, L.; Dieli-Conwright, C.M.; Mortimer, J.E. The impact of obesity on breast cancer diagnosis and treatment. Curr Oncol. Rep. 2019, 21, 41. [CrossRef] [PubMed]

149. Shekhawat, R.; Mandal, C.C. Anti-obesity medications in cancer therapy: A comprehensive insight. Curr. Cancer Drug Targets 2021, 21, 476-494. [CrossRef] [PubMed]

150. Sirin, O.; Kolonin, M.G. Treatment of obesity as a potential complementary approach to cancer therapy. Drug Discov. Today 2013, 18, 567-573. [CrossRef] [PubMed]

151. Yuan, Y.; Pan, K.; Mortimer, J.; Chlebowski, R.T.; Luo, J.; Yan, J.E.; Yost, S.E.; Kroenke, C.H.; Adams-Campbell, L.; Nassir, R.; et al. Metabolic syndrome risk components and mortality after triple-negative breast cancer diagnosis in postmenopausal women in the Women's Health Initiative. Cancer 2021, 127, 1658-1667. [CrossRef]

152. Quagliariello, V.; Bonelli, A.; Caronna, A.; Conforti, G.; Iovine, M.; Carbone, A.; Berretta, M.; Botti, G.; Maurea, N. SARS-CoV-2 infection and cardioncology: From cardiometabolic risk factors to outcomes in cancer patients. Cancers 2020, 12, 3316. [CrossRef]

153. Gardiner, J.; Oben, J.; Sutcliffe, A. Obesity as a driver of international differences in COVID-19 death rates. Diabetes Obes. Metab. 2021, 23, 1463-1470. [CrossRef]

154. Pena, J.E.; Rascon-Pacheco, R.A.; Ascencio-Montiel, I.J.; Gonzalez-Figueroa, E.; Fernandez-Garate, J.E.; Medina-Gomez, O.S.; Borja-Bustamante, P.; Santillan-Oropeza, J.A.; Borja-Aburto, V.H. Hypertension, diabetes and obesity, major risk factors for death in patients with COVID-19 in Mexico. Arch. Med. Res. 2021, 52, 443-449. [CrossRef]

155. Rottoli, M.; Bernante, P.; Belvedere, A.; Balsamo, F.; Garelli, S.; Giannella, M.; Cascavilla, A.; Tedeschi, S.; Ianniruberto, S.; Rosselli Del Turco, E.; et al. How important is obesity as a risk factor for respiratory failure, intensive care admission and death in hospitalised COVID-19 patients? Results from a single Italian centre. Eur. J. Endocrinol. 2020, 183, 389-397. [CrossRef]

156. Kiwata, J.L.; Dorff, T.B.; Schroeder, E.T.; Gross, M.E.; Dieli-Conwright, C.M. A review of clinical effects associated with metabolic syndrome and exercise in prostate cancer patients. Prostate Cancer Prostatic Dis. 2016, 19, 323-332. [CrossRef]

157. Bandera, E.V.; Alfano, C.M.; Qin, B.; Kang, D.W.; Friel, C.P.; Dieli-Conwright, C.M. Harnessing nutrition and physical activity for breast cancer prevention and control to reduce racial/ethnic cancer health disparities. Am. Soc. Clin. Oncol. Educ. Book 2021, 41, 1-17. [CrossRef] 
158. Dieli-Conwright, C.M.; Courneya, K.S.; Demark-Wahnefried, W.; Sami, N.; Lee, K.; Sweeney, F.C.; Stewart, C.; Buchanan, T.A.; Spicer, D.; Tripathy, D.; et al. Aerobic and resistance exercise improves physical fitness, bone health, and quality of life in overweight and obese breast cancer survivors: A randomized controlled trial. Breast Cancer Res. 2018, 20, 124. [CrossRef]

159. Dieli-Conwright, C.M.; Courneya, K.S.; Demark-Wahnefried, W.; Sami, N.; Norris, M.K.; Fox, F.S.; Buchanan, T.A.; Spicer, D.; Bernstein, L.; Tripathy, D. Aerobic and resistance exercise improve patient-reported sleep quality and is associated with cardiometabolic biomarkers in Hispanic and non-Hispanic breast cancer survivors who are overweight or obese: Results from a secondary analysis. Sleep 2021, 44, zsab111. [CrossRef]

160. Dieli-Conwright, C.M.; Sami, N.; Norris, M.K.; Wan, J.; Kumagai, H.; Kim, S.J.; Cohen, P. Effect of aerobic and resistance exercise on the mitochondrial peptide MOTS-c in Hispanic and Non-Hispanic White breast cancer survivors. Sci. Rep. 2021, 11, 16916. [CrossRef]

161. Kiwata, J.L.; Dorff, T.B.; Todd Schroeder, E.; Salem, G.J.; Lane, C.J.; Rice, J.C.; Gross, M.E.; Dieli-Conwright, C.M. A pilot randomised controlled trial of a periodised resistance training and protein supplementation intervention in prostate cancer survivors on androgen deprivation therapy. BMJ Open 2017, 7, e016910. [CrossRef]

162. Lee, K.; Kang, I.; Mack, W.J.; Mortimer, J.; Sattler, F.; Salem, G.; Dieli-Conwright, C.M. Effect of high intensity interval training on matrix metalloproteinases in women with breast cancer receiving anthracycline-based chemotherapy. Sci. Rep. 2020, 10, 5839. [CrossRef]

163. Lee, K.; Sami, N.; Tripathy, D.; Demark-Wahnefried, W.; Norris, M.K.; Courneya, K.S.; Dieli-Conwright, C.M. Aerobic and resistance exercise improves Reynolds risk score in overweight or obese breast cancer survivors. Cardiooncology 2020, 6, 27. [CrossRef]

164. Lee, K.; Zhou, J.; Norris, M.K.; Chow, C.; Dieli-Conwright, C.M. Prehabilitative exercise for the enhancement of physical, psychosocial, and biological outcomes among patients diagnosed with cancer. Curr. Oncol. Rep. 2020, 22, 71. [CrossRef]

165. Mortimer, J.E.; Waliany, S.; Dieli-Conwright, C.M.; Patel, S.K.; Hurria, A.; Chao, J.; Tiep, B.; Behrendt, C.E. Objective physical and mental markers of self-reported fatigue in women undergoing (neo)adjuvant chemotherapy for early-stage breast cancer. Cancer 2017, 123, 1810-1816. [CrossRef]

166. De Oliveira Faria, S.; Hurwitz, G.; Kim, J.; Liberty, J.; Orchard, K.; Liu, G.; Barbera, L.; Howell, D. Identifying patient-reported outcome measures (PROMs) for routine surveillance of physical and emotional symptoms in head and neck cancer populations: A systematic review. J. Clin. Med. 2021, 10, 4162. [CrossRef]

167. Efficace, F.; Cella, D.; Aaronson, N.K.; Calvert, M.; Cottone, F.; Di Maio, M.; Perrone, F.; Sparano, F.; Gamper, E.M.; Vignetti, M.; et al. Impact of blinding on patient-reported outcome differences between treatment arms in cancer randomized controlled trials. J. Natl. Cancer Inst. 2021, 44, zsab111. [CrossRef]

168. Elting, L.S.; Keefe, D.M.; Sonis, S.T.; Garden, A.S.; Spijkervet, F.K.; Barasch, A.; Tishler, R.B.; Canty, T.P.; Kudrimoti, M.K.; Vera-Llonch, M.; et al. Patient-reported measurements of oral mucositis in head and neck cancer patients treated with radiotherapy with or without chemotherapy: Demonstration of increased frequency, severity, resistance to palliation, and impact on quality of life. Cancer 2008, 113, 2704-2713. [CrossRef]

169. Vyas, A.; Alghaith, G.; Hufstader-Gabriel, M. Psychotropic polypharmacy and its association with health-related quality of life among cancer survivors in the USA: A population-level analysis. Qual. Life Res. 2020, 29, 2029-2037. [CrossRef] 